\title{
A COORDENAÇÃO FEDERATIVA NO BRASIL: A EXPERIÊNCIA DO PERÍODO FHC E OS DESAFIOS DO GOVERNO LULA ${ }^{1}$
}

\author{
Fernando Luiz Abrucio
}

\begin{abstract}
RESUMO
O renascimento da federação brasileira com a redemocratização trouxe uma série de aspectos alvissareiros, mas o Brasil também precisa enfrentar os crescentes dilemas de coordenação intergovernamental constatados internacionalmente, de acordo com as especificidades históricas de nossa realidade. O presente artigo concentra-se basicamente no estudo dos problemas e ações de coordenação federativa ocorridas recentemente no Brasil, mais particularmente no período governamental do Presidente Fernando Henrique Cardoso. A partir desta análise, procura-se, ao final, apresentar resumidamente os desafios de coordenação intergovernamental colocados para o governo Lula.
\end{abstract}

PALAVRAS-CHAVE: federação; centralização; descentralização; governo FHC; governo Lula.

\section{INTRODUÇÃO}

A estrutura federativa é um dos balizadores mais importantes do processo político no Brasil. Ela tem afetado a dinâmica partidário-eleitoral, o desenho das políticas sociais e o processo de reforma do Estado. Além de sua destacada influência, a federação vem passando por intensas modificações desde a redemocratização do país. É possível dizer, tendo como base a experiência comparada recente, que o federalismo brasileiro é atualmente um dos casos mais ricos e complexos entre os sistemas federais existentes.

Diante de tudo isso, cresce o número de pesquisas sobre o assunto, de estudiosos brasileiros e estrangeiros. Embora esses trabalhos comportem abordagens de campos científicos diferentes, diversidades de temas e divergências de interpretação, há um elemento comum à maioria deles. Grosso modo, os estudos sobre o federalis-

\footnotetext{
${ }^{1}$ Este artigo baseia-se em duas pesquisas. A primeira foi feita em 2002, para o Ministério do Planejamento e o Programa da Organização das Nações Unidas para o Desenvolvimento, que resultou na publicação $O$ Estado em uma era de reformas: os anos FHC. A segunda chama-se Reforma do Estado, federalismo e elites políticas: o governo Lula em perspectiva comparada e está em andamento, tendo como financiador o Núcleo de Publicação e Pesquisas (NPP) da Fundação Getúlio Vargas.
}

mo brasileiro privilegiam a análise do embate, hoje e ao longo da história, entre o governo federal e os entes subnacionais, por meio de suas elites políticas e estruturas de poder. As oposições descentralização versus centralização (ou recentralização) e o poder dos governadores frente à força das instâncias nacionais - os partidos e/ou o Presidente da República - dominam boa parte do debate. Esse foco analítico é uma peça-chave na investigação das relações intergovernamentais, mas ele não esgota o seu entendimento e, pior, não leva sozinho à compreensão do funcionamento dos sistemas federais.

É preciso acrescentar outro vetor analítico, pouco explorado no Brasil, bem como no estudo de outros países. Trata-se da análise do problema da coordenação intergovernamental, isto é, das formas de integração, compartilhamento e decisão conjunta presentes nas federações. Essa questão torna-se bastante importante com a complexificação das relações intergovernamentais ocorrida em todo o mundo nos últimos anos. Isso se deveu à convivência de tendências conflituosas e de intrincada solução, entre as quais se destacam três:

a) há hoje expansão ou, no mínimo, manutenção do Welfare State convivendo com maior escassez relativa de recursos. Tal situação exige melhor desempenho governamental, com fortes pressões por economia (cortar gastos e cus- 
tos), eficiência (fazer mais com menos) e efetividade (ter impacto sobre as causas dos problemas sociais) - três tópicos que dependem, em países federativos, de maior coordenação entre as esferas político-administrativas na gestão das políticas públicas;

b) houve um aumento das demandas por maior autonomia de governos locais e/ou grupos étnicos, levando à luta contra a uniformização e a excessiva centralização, o que acontece ao mesmo tempo em que governos e coalizões nacionais tentam evitar problemas causados pela fragmentação, como a elevação da desigualdade social, o descontrole das contas públicas de entes subnacionais - como ocorreu na Argentina e no Brasil -, a guerra fiscal entre os níveis de governo e, no piores casos, o surgimento de focos de secessão, como na Rússia e

c) se, por um lado, é cada vez maior a interconexão dos governos locais com outras estruturas de poder que não os governos centrais, tais como os relacionamentos com forças transnacionais - como empresas e organismos internacionais - e as parcerias com a sociedade civil, por outro lado, há simultaneamente uma necessidade de reforço das instâncias nacionais para organizar melhor a inserção internacional do país e reduzir os aspectos negativos da globalização, inclusive para as comunidades locais e seus hábitos socioculturais.

Conflitos e dilemas como esses revelam, em suma, que a temática da coordenação federativa tem como intuito ir além da dicotomia centralização versus descentralização. Em recente estudo feito pela Organization for the Economic Cooperation and Development (OECD), com base em diversas federações, concluiu-se que "Há tempos ocorrem debates sobre centralização ou descentralização. Nós precisamos agora estar dispostos a mover em ambas as direções - descentralizando algumas funções e ao mesmo tempo centralizando outras responsabilidades cruciais na formulação de políticas. Tais mudanças estão a caminho em todos os países"2 (OECD, 1997, p. 13).

O renascimento da federação brasileira com a redemocratização trouxe uma série de aspectos

\footnotetext{
2 Todos as citações cujos originais são em língua estrangeira foram traduzidas pelo autor.
}

alvissareiros, mas o Brasil também precisa enfrentar os crescentes dilemas de coordenação intergovernamental constatados internacionalmente, de acordo com as especificidades históricas de nossa realidade. O presente artigo concentrase basicamente no estudo dos problemas e ações de coordenação federativa ocorridas recentemente no Brasil, mais particularmente no período governamental do Presidente Fernando Henrique Cardoso (FHC). A partir desta análise, procurase, ao final, apresentar resumidamente os desafios de coordenação intergovernamental colocados para o governo Lula.

\section{O SIGNIFICADO DA COORDENAÇÃO FE- DERATIVA}

A temática da descentralização ganhou força nos últimos 30 anos em todo o mundo. Sua implementação diferencia-se, no entanto, de país a país, de acordo com especificidades históricas, coalizões sociais e arranjos institucionais. Dentre estes últimos, a adoção de uma forma federativa de Estado é a que tem maior impacto.

O sistema federal é uma forma inovadora de lidar-se com a organização político territorial do poder, na qual há um compartilhamento matricial da soberania e não piramidal, mantendo-se a estrutura nacional (ELAZAR, 1987, p. 37). O entendimento da especificidade do federalismo passa pela análise de sua natureza, de seu significado e de sua dinâmica.

Primeiramente, toda federação deriva de uma situação federalista (BURGESS, 1993). Duas condições conformam esse cenário. Uma é a existência de heterogeneidades que dividem uma determinada nação, de cunho territorial (grande extensão e/ou enorme diversidade física), étnico, lingüístico, sócio-econômico (desigualdades regionais), cultural e político (diferenças no processo de constituição das elites dentro de um país e/ou uma forte rivalidade entre elas). Qualquer país federativo foi assim instituído para dar conta de uma ou mais heterogeneidades. Se um país desse tipo não constituir uma estrutura federativa, dificilmente a unidade nacional manterá a estabilidade social ou, no limite, a própria nação corre risco de fragmentação.

Outra condição federalista é a existência de um discurso e de uma prática defensores da unidade na diversidade, resguardando a autonomia local, mas procurando formas de manter a integridade territorial em um país marcado por heterogenei- 
dades. A coexistência dessas duas condições é essencial para montar-se um pacto federativo. Mas que é uma federação? Segundo Daniel Elazar, “O termo 'federal' é derivado do latim foedus, que [...] significa pacto. Em essência, um arranjo federal é uma parceria, estabelecida e regulada por um pacto, cujas conexões internas refletem um tipo especial de divisão de poder entre os parceiros, baseada no reconhecimento mútuo da integridade de cada um e no esforço de favorecer uma unidade especial entre eles” (ELAZAR, 1987, p. 5).

O princípio da soberania compartilhada deve garantir a autonomia dos governos e a interdependência entre eles. Trata-se da fórmula classicamente enunciada por Daniel Elazar: selfrule plus shared rule ${ }^{3}$. Quanto ao primeiro aspecto, é importante ressaltar que os níveis intermediários e locais detêm a capacidade de autogoverno como em qualquer processo de descentralização, com grande raio de poder nos terrenos político, legal, administrativo e financeiro, mas sua força política vai além disso. A peculiaridade da federação reside exatamente na existência de direitos originários pertencentes aos pactuantes subnacionais - sejam estados, províncias, cantões ou até municípios, como no Brasil. Tais direitos não podem ser arbitrariamente retirados pela União e são, além do mais, garantidos por uma Constituição escrita, o principal contrato fiador do pacto político-territorial.

Ressalte-se que na federação o poder nacional deriva de um acordo entre as partes, em vez de constituí-las. Assim, a descentralização em estados unitários pode até repassar um efetivo poder político, mas esse processo sempre provém do centro e não constitui direitos de soberania aos entes subnacionais.

Os governos subnacionais também têm instrumentos políticos para defender seus interesses e direitos originários, quais sejam, a existência de cortes constitucionais, que garantem a integridade contratual do pacto originário; uma segunda casa legislativa representante dos interesses regionais (Senado ou correlato); a representação desproporcional dos estados/províncias menos populosos (e muitas vezes mais pobres) na câmara baixa e o grande poder de limitar mudanças na

3 “Autogoverno mais governo compartilhado" (nota do revisor).
Constituição, criando um processo decisório mais intrincado, que exige maiorias qualificadas e, em muitos casos, é necessária a aprovação dos legislativos estaduais ou provinciais. E mais: alguns princípios básicos da federação não podem ser emendados em hipótese alguma.

Como bem constatou Alfred Stepan, toda federação restringe o poder da maioria ("demos constraining”), consubstanciado na esfera nacional. Porém, o federalismo precisa igualmente responder à questão da interdependência entre os níveis de governo. A exacerbação de tendências centrífugas, da competição entre os entes e do repasse de custos do plano local ao nacional são formas que devem ser atacadas em qualquer experiência federativa, sob o risco de enfraquecerse a unidade político-territorial ou de torná-la ineficaz para resolver a "tragédia dos comuns” típica do federalismo, vinculada a problemas de heterogeneidade. $\mathrm{O}$ fato é que a soberania compartilhada só pode ser mantida ao longo do tempo caso estabeleça-se uma relação de equilíbrio entre a autonomia dos pactuantes e sua interdependência.

A interdependência federativa não pode ser alcançada pela mera ação impositiva e piramidal de um governo central, tal qual em um Estado unitário, pois uma federação supõe uma estrutura mais matricial, sustentada por uma soberania compartilhada. É claro que as esferas superiores de poder estabelecem relações hierárquicas frente às demais, seja em termos legais, seja em virtude do auxílio e do financiamento às outras unidades governamentais. O governo federal tem prerrogativas específicas para manter o equilíbrio federativo e os governos intermediários igualmente detêm forte grau de autoridade sobre as instâncias locais ou comunais. Mas a singularidade do modelo federal está na maior horizontalidade entre os entes, devido aos direitos originários dos pactuantes subnacionais e à sua capacidade política de proteger-se. Em poucas palavras, processos de barganha afetam decisivamente as relações verticais em um sistema federal.

O compartilhamento de poder e decisão em uma federação, desde a sua invenção nos Estados Unidos, pressupõe a existência de controles mútuos entre os níveis de governo - trata-se dos

\footnotetext{
4 “Freios e contrapesos” (N. R.).
} 
checks and balances ${ }^{4}$. O objetivo desse mecanismo é a fiscalização recíproca entre os entes federativos para que nenhum deles concentre indevidamente poder e, desse modo, acabe com a autonomia dos demais. Assim sendo, a busca da interdependência em uma federação democrática tem de ser feita conjuntamente com o controle mútuo.

Mas, além da garantia da autoridade nacional sem retirar a autonomia local e da necessidade de checks and balances entre os níveis de governo, um novo aspecto torna mais complexo o funcionamento das federações. É que o desenvolvimento recente dos estados modernos levou ao crescimento do papel dos governos centrais, especialmente no que se refere à expansão das políticas sociais. No caso dos sistemas federais, em que vigora uma soberania compartilhada, constituiuse um processo negociado e extenso de shared decision making 5 , ou seja, de compartilhamento de decisões e responsabilidades. A interdependência enfrenta aqui o problema da coordenação das ações de níveis de governo autônomos, aspecto-chave para entender a produção de políticas públicas em uma estrutura federativa contemporânea.

Em seu trabalho sobre os estados de Bem-estar Social em países unitários e federativos, Paul Pierson (1995) revela que no federalismo as ações governamentais são divididas entre unidades políticas autônomas, as quais, porém, têm cada vez mais interconexão, devido à nacionalização dos programas e mesmo da fragilidade financeira ou administrativa de governos locais e/ou regiões. O dilema do shared decision making surge porque é preciso compartilhar políticas entre entes federativos que, por natureza, só entram nesse esquema conjunto se assim o desejarem. Desse modo, a montagem dos Welfare States nos países federativos é bem mais complexa, envolvendo jogos de cooperação e competição, acordos, vetos e decisões conjuntas entre os níveis de governo. O desafio posto por essa questão foi bem resumido por Pierson: "No federalismo, dada a divisão de poderes entre os entes, as iniciativas políticas são altamente interdependentes, mas são, de modo freqüente, modestamente coordenadas" (PIERSON, 1995, p. 451).

\footnotetext{
5 “Processo decisório compartilhado” (N. R.).
}

Para garantir a coordenação entre os níveis de governo, as federações devem, primeiramente, equilibrar as formas de cooperação e competição existentes, levando em conta que o federalismo é intrinsecamente conflitivo. Seguindo essa linha argumentativa, Paul Pierson assim define o funcionamento das relações intergovernamentais no federalismo: "Mais do que um simples cabo de guerra, as relações intergovernamentais requerem uma complexa mistura de competição, cooperação e acomodação" (idem, p. 458). Daí toda federação ter de combinar formas benignas de cooperação e competição. No caso da primeira, não se trata de impor formas de participação conjunta, mas de instaurar mecanismos de parceria que sejam aprovados pelos entes federativos. O modus operandi cooperativo é fundamental para otimizar a utilização de recursos comuns, como nas questões ambientais ou problemas de ação coletiva que cobrem mais de uma jurisdição (caso dos transportes metropolitanos); para auxiliar governos menos capacitados ou mais pobres a realizarem determinadas tarefas e para integrar melhor o conjunto de políticas públicas compartilhadas, evitando o jogo de empurra entre os entes. Ainda é peçachave no ataque a comportamentos financeiros predatórios, que repassam custos de um ente à nação, como também na distribuição de informação sobre as fórmulas administrativas bem-sucedidas, incentivando o associativismo intergovernamental.

Não se pode esquecer, também, que o modelo cooperativo contribui para elevar a esperança quanto à simetria entre os entes territoriais, fator fundamental para o equilíbrio de uma federação. No entanto, fórmulas cooperativas mal-dosadas trazem problemas. Isso ocorre quando a cooperação confunde-se com a verticalização, resultando mais em subordinação do que em parceria, como muitas vezes já aconteceu na realidade latino-americana, de forte tradição centralizadora.

É também perigosa a montagem daquilo que Fritz Scharpf (1988) denomina joint decision trap (armadilha da decisão conjunta), bastante visível no caso alemão, mas que se repete igualmente em outras experiências. Nessa estrutura, todas as decisões são o máximo possível compartilhadas e dependem da anuência de praticamente todos os atores federativos. Sem desmerecer os ganhos de racionalidade administrativa, tende-se à uniformização das políticas, processo que pode diminuir o ímpeto inovador dos níveis de governo, enfraque- 
cer os checks and balances intergovernamentais e dificultar a responsabilização da administração pública.

As federações requerem determinadas formas de competição entre os níveis de governo. Primeiro, devido à importância dos controles mútuos como instrumento contra a dominância (ou tirania, nos termos de Madison) de um nível de governo sobre os demais. Além disso, a competição federativa pode favorecer a busca pela inovação e pelo melhor desempenho das gestões locais, já que os eleitores podem comparar o desempenho dos vários governantes, uma das vantagens de ter-se uma multiplicidade de governos. A concorrência e a independência dos níveis de governo, por fim, tendem a evitar os excessos contidos na "armadilha da decisão conjunta", bem como o paternalismo e o parasitismo causados por certa dependência em relação às esferas superiores de poder.

Há uma série de problemas advindos de competições desmedidas. O primeiro refere-se ao excesso de concorrência, que afeta a solidariedade entre as partes, ponto fulcral do equilíbrio federativo. Quanto mais heterogêneo é um país, em termos socioculturais ou sócio-econômicos, mais complicada é a adoção única e exclusiva da visão competitiva do federalismo. Países como a Índia, o Brasil ou a Rússia devem por sua natureza evitar uma disputa desregrada entre os entes.

A competição em prol da inovação também pode ter efeitos negativos, mais particularmente no terreno das políticas sociais, como demonstrou o livro de Paul Peterson (The Price of Federalism, 1995) sobre a experiência recente dos governos estaduais norte-americanos. O autor percebeu o fortalecimento de uma visão acerca do federalismo: a de que os cidadãos "votam com os pés” 6 , ou seja, podem escolher o lugar que otimize melhor a relação entre carga tributária e políticas públicas. Diante disso, os estados ficaram entre duas opções: ou forneciam um cardápio amplo de proteção social, tendo como efeito um Welfare magnets ${ }^{7}$, isto é, mais pessoas, sobretudo as mais pobres, morariam nesses lugares, aumentando os gastos públicos e, em tese,

\footnotetext{
6 Essa visão foi formulada originalmente por Charles Tiebout (1956).

7 “Ímãs de bem-estar” (N. R.).
}

diminuindo a competitividade econômica daquele lugar; ou, ao contrário, os governadores deveriam constituir uma estrutura mínima de prestação de serviços públicos e baixar os impostos, reduzindo com isso a afluência dos mais pobres àquela região e, novamente em tese, elevando a competitividade econômica e a oferta de emprego do ente federativo que optasse por esta via - é o que Peterson denomina race to the bottom ${ }^{8}$.

Entre o efeito de Welfare magnets e o race to the bottom, muitos governadores nos EUA estão escolhendo a segunda opção, de modo que o aumento da competição vem acompanhado da redução de políticas de combate à desigualdade. Em suma, o modelo competitivo levado ao extremo piora a questão redistributiva.

O federalismo puramente competitivo vem estimulando, ainda, a guerra fiscal entre os níveis de governo. Trata-se de um leilão que exige mais e mais isenções às empresas, em que cada governo subnacional procura oferecer mais do que o outro, geralmente sem se preocupar com a forma de custear esse processo. Ao fim e ao cabo, a resolução financeira dessa questão toma rumos predatórios, seja acumulando dívidas para as próximas gerações, seja repassando tais custos para o nível federal e, por tabela, para a nação como um todo.

O desafio é encontrar caminhos que permitam a melhor adequação entre competição e cooperação, procurando ressaltar seus aspectos positivos em detrimento dos negativos. Recorrendo mais uma vez à argumentação precisa de Daniel Elazar: "[...] todo sistema federal, para ser bem sucedido, deve desenvolver um equilíbrio adequado entre cooperação e competição e entre o governo central e seus componentes” (ELAZAR, 1993, p. 193; sem grifos no original).

A coordenação federativa pode realizar-se, em primeiro lugar, por meio de regras legais que obriguem os atores a compartilhar decisões e tarefas - definição de competências no terreno das políticas públicas, por exemplo. Além disso, podem existir fóruns federativos, com a participação dos próprios entes - como os senados em geral - ou que eles possam acionar na defesa de seus direitos - como as cortes constitucionais. A constru-

\footnotetext{
8 “Corrida ao fundo do poço" (N. R.).
} 
ção de uma cultura política baseada no respeito mútuo e na negociação no plano intergovernamental é outro elemento importante. A forma de funcionamento das instituições representativas, tais como os partidos e o Parlamento, pode favorecer certos resultados intergovernamentais (ARRETCHE, 2004).

O governo federal também pode ter um papel coordenador e/ou indutor. Por um lado, porque em vários países os governos subnacionais têm problemas financeiros e administrativos que dificultam a assunção de encargos. Por outro, porque a União tem por vezes a capacidade de arbitrar conflitos políticos e de jurisdição, além de incentivar a atuação conjunta e articulada entre os níveis de governo no terreno das políticas públicas.

A atuação coordenadora do governo federal ou de outras instâncias federativas não pode ferir os princípios básicos do federalismo, como a autonomia e os direitos originários dos governos subnacionais, a barganha e o pluralismo associados ao relacionamento intergovernamental e os controles mútuos. É preciso, portanto, que haja processos decisórios com participação das esferas de poder e estabelecer redes federativas (ABRUCIO \& SOARES, 2001) e não hierarquias centralizadoras.

Definido o conceito de federalismo e a importância da coordenação intergovernamental dentro dele, o propósito central deste texto é analisar o caso brasileiro, centrando o foco no período governamental do Presidente Fernando Henrique Cardoso (1995-2002). Mais especificamente, o objetivo primordial é mostrar como o governo federal, na Era FHC, lidou com a questão da coordenação entre os níveis de governo. As ações de outras instâncias que podem lidar com esse tema não serão negligenciadas, mas deverão ser entendidas a partir da estratégia adotada pelo poder Executivo federal.

\section{A REDEMOCRATIZAÇÃO E O NOVO FE- DERALISMO BRASILEIRO}

A história federativa brasileira foi marcada por sérios desequilíbrios entre os níveis de governo. No período inicial, na República Velha, predominou um modelo centrífugo, com estados tendo ampla autonomia, pouca cooperação entre si e um governo federal bastante fraco. Nos anos Vargas, o Estado nacional fortaleceu-se, mas os governos estaduais, particularmente no Estado Novo, perderam a autonomia. O interregno 1946-1964 foi o primeiro momento de maior equilíbrio em nossa federação, tanto do ponto de vista da relação entre as esferas de poder como da prática democrática. Mas o golpe militar acabou com esse padrão e por cerca de 20 anos manteve um modelo unionista autoritário (ABRUCIO, 1998), com grande centralização política, administrativa e financeira.

A redemocratização do país marcou um novo momento no federalismo. As elites regionais, particularmente os governadores, foram fundamentais para o desfecho da transição democrática, desde as eleições estaduais de 1982, passando pela vitória de Tancredo Neves no Colégio Eleitoral ele próprio, não coincidentemente, um governador de estado - até chegar à Nova República e à Constituinte. Além disso, lideranças de discurso municipalista associavam o tema da descentralização à democracia e também participaram ativamente na formulação de diversos pontos da Constituição de 1988.

Um novo federalismo nascia no Brasil. Ele foi resultado da união entre forças descentralizadoras democráticas com grupos regionais tradicionais que se aproveitaram do enfraquecimento do governo federal em um contexto de esgotamento do modelo varguista e do Estado nacionaldesenvolvimentista a ele subjacente. O seu projeto básico era fortalecer os governos subnacionais e, para uma parte desses atores, democratizar o plano local. Preocupações com a fragilidade dos instrumentos nacionais de atuação e com coordenação federativa ficaram em segundo plano.

Dois fenômenos destacam-se nesse novo federalismo brasileiro, desenhado na década de 1980 e com reflexos ao longo dos anos 1990. Primeiro, o estabelecimento de um amplo processo de descentralização, tanto em termos financeiros como políticos. Em segundo lugar, a criação de um modelo predatório e não-cooperativo de relações intergovernamentais, com predomínio do componente estadualista.

Comecemos pela formação do federalismo estadualista e predatório, visto que ele teve um impacto enorme nos primórdios do novo federalismo brasileiro. De 1982 a 1994, vigorou um federalismo estadualista, não-cooperativo e muitas vezes predatório (ABRUCIO, 1998). Essa reviravolta na federação brasileira só pôde efetivar-se, 
em primeiro lugar, porque a União e a própria Presidência da República entraram em uma séria crise, que perdurou por pelo menos dez anos. A crise abarcava o modelo de financiamento estatal do desenvolvimento, o equilíbrio das contas públicas nacionais e a burocracia federal - enfim, os instrumentos de poder do Executivo federal.

Além do enfraquecimento do pólo nacional, outras quatro características do sistema político também contribuíram para aumentar o poderio dos estados e de seus governadores. A primeira delas foi a vigência de um sistema ultrapresidencial nos estados - que em grande medida ainda vigora -, que fortaleceu sobremaneira os governadores no processo decisório e praticamente eliminou o controle institucional e social sobre o seu poder (idem, cap. 3). A segunda diz respeito aos padrões hegemônicos da carreira política brasileira, cuja reprodução dá-se pela lealdade às bases locais e pela obtenção de cargos executivos no plano subnacional ou então aqueles no nível nacional que possam trazer recursos aos "distritos" dos políticos. Em ambos os casos, o Executivo estadual é peça fundamental, seja no monitoramento das bases para os deputados, seja para ajudá-los na conquista de fatias estratégicas da administração pública federal (ABRUCIO \& SAMUELS, 1997).

Os caciques regionais tiveram uma posição destacada de liderança no Congresso Nacional ao longo da redemocratização, por vezes a despeito dos partidos, por outras tornando-se grandes proprietários de parcelas dos condomínios partidários. Por fim, os governadores possuíam instrumentos financeiros e administrativos que os fortaleciam no sistema de poder, como bancos estaduais e empresas estatais estratégicas.

O fortalecimento dos governos estaduais resultou na configuração de um federalismo estadualista e predatório. Estadualista porque o pêndulo federativo esteve a favor das unidades estaduais em termos políticos e financeiros, pelo menos até 1994, quando se implementou o Plano Real. Esse aspecto estava igualmente presente no comportamento atomizado e individualista dos governadores, cujo fortalecimento não resultou em uma coalizão nacional em torno de um projeto de hegemonia nacional, mas sim em coalizões pontuais e defensivas para manter o status quo.

O caráter predatório do federalismo brasileiro resultou do padrão de competição não-cooperativa que predominava nas relações dos estados com a União e deles entre si. Desde o final do regime militar, as relações intergovernamentais verticais tinham sido marcadas pela capacidade de os estados repassarem seus custos e dívidas ao governo federal e, ainda por cima, não se responsabilizarem por este processo, mesmo quando assinavam contratos federativos. Caso clássico disso foram os bancos estaduais. A partir de 1982, as instituições financeiras estaduais foram utilizadas pelos governadores como instrumento de atuação política. Foram criadas verdadeiras máquinas de produzir moedas, com efeitos deletérios para a inflação e para o endividamento global.

No plano das relações entre os estados, o aspecto predatório teve sua principal manifestação na guerra fiscal, que começou a ganhar força após a Constituição de 1988 e ainda continua vigorosa nas práticas federativas. O fato é que o estadualismo predatório acabou sendo ele próprio um dos elementos geradores de sua crise, em 1994, como veremos mais adiante.

Esse contexto estadualista tem algo em comum com a descentralização: o intento de reforçar os governos subnacionais, obtendo-se uma autonomia inédita. A federação tornou-se uma cláusula pétrea e sua extinção ou medidas que alterem profundamente seus princípios não podem ser objetos de emenda constitucional (artigo 60, parágrafo 4 da Constituição Federal de 1988). Os estados ganharam maior capacidade de auto-organização e novos instrumentos de atuação no plano intergovernamental, como as Ações Diretas de Inconstitucionalidade (ADINs), extensamente utilizadas pelos governadores (WERNECK VIANNA, 1999, p. 55).

Pela primeira vez na história, os municípios transformaram-se em entes federativos, constitucionalmente com o mesmo status jurídico que os estados e a União ${ }^{9}$. Não obstante essa autonomia, os governos locais respeitam uma linha hierárquica quanto à sua capacidade jurídica - a Lei Orgânica, por exemplo, não pode contrariar frontalmente a Constituição estadual -, e são, no mais das vezes, muito dependentes dos níveis superiores de governo no que tange às questões políti-

9 Já no seu artigo 1, a Constituição define que “a República Federativa do Brasil [é] formada pela união indissolúvel dos Estados e Municípios e do Distrito Federal [...]” (BRASIL, 1988). 
cas, financeiras e administrativas.

A nova autonomia dos governos subnacionais deriva em boa medida das conquistas tributárias, iniciadas com a Emenda Passos Porto, em 1983, e consolidadas na Constituição de 1988, o que faz do Brasil o país em desenvolvimento com maior grau de descentralização fiscal (SOUZA, 1998, p. 8). Cabe ressaltar que os municípios tiveram a maior elevação relativa na participação do bolo tributário, apesar de grande parte deles depender muito dos recursos econômicos e administrativos das demais esferas de governo. $\mathrm{O}$ fato é que os constituintes reverteram a lógica centralizadora do modelo unionista-autoritário e mesmo as recentes alterações que beneficiaram a União não modificaram a essência descentralizadora das finanças públicas brasileiras.

A descentralização foi acompanhada igualmente pela tentativa de democratizar o plano local. Embora esse processo seja desigual na sua distribuição pelo país e tenha um longo caminho pela frente, ele redundou em uma pressão sobre as antigas estruturas oligárquicas, conformando um fenômeno sem paralelo em nossa história federativa. Daí surgiram novos atores, como os conselheiros em políticas públicas e líderes políticos que não tinham acesso real à competição pelo poder o crescimento gradativo da esquerda nas eleições municipais, em particular o Partido dos Trabalhadores (PT), demonstra isso. Também surgiram formas inovadoras de gestão, como o orçamento participativo e a Bolsa-Escola, para ficar com dois casos famosos.

As conquistas da descentralização não apagam os problemas dos governos locais brasileiros. Em especial, cinco são as questões que colocam obstáculos ao bom desempenho dos municípios do país: a desigualdade de condições econômicas e administrativas; o discurso do "municipalismo autárquico"; a "metropolização” acelerada; os resquícios ainda existentes tanto de uma cultura política como de instituições que dificultam a accountability democrática e o padrão de relações intergovernamentais.

Desde a fundação da federação, o Brasil é historicamente marcado por fortes desigualdades regionais, inclusive em comparação com outros países. A disparidade de condições econômicas é reforçada, ademais, pela existência de um contingente enorme de municípios pequenos, com baixa capacidade de sobreviver apenas com recur- sos próprios. A média por região é de $75 \%$ dos municípios com até 50 mil habitantes, ao passo que no universo total há 91\% dos poderes locais com esse contingente populacional (ARRETCHE, 2000, p. 247).

A baixa capacidade tributária dos municípios brasileiros é ainda maior sob o ponto de vista comparado. Segundo estudo realizado por José Roberto Afonso e Érica Araújo (2000, p. 48), os governos locais brasileiros estavam em $15^{\circ}$ lugar em termos de base de arrecadação própria em um universo de 19 países. Mas, além da fragilidade financeira, a maior parcela das municipalidades detém uma máquina administrativa precária.

Somado ao obstáculo financeiro e administrativo, o bom andamento da descentralização no Brasil foi prejudicado pelo municipalismo autárquico, visão que prega a idéia de que os governos locais poderiam sozinhos resolver todos os dilemas de ação coletiva colocados às suas populações. Essa definição foi elaborada por Celso Daniel, ex-Prefeito de Santo André (em 2001), um dos grandes defensores da bandeira municipalista, além de um inovador administrativo e um democratizador das relações entre Estado e sociedade, mas que também sabia dos limites do poder local no país.

O municipalismo autárquico incentiva, em primeiro lugar, a "prefeiturização", tornando os prefeitos atores por excelência do jogo local e intergovernamental. Cada qual defende seu município como uma unidade legítima e separada das demais, o que é uma miopia em relação aos problemas comuns em termos "micro" e macrorregionais. Ademais, há poucos incentivos para que os municípios consorciem-se, dado que não existe nenhuma figura jurídica de direito público que dê segurança política para os governos locais que buscam criar mecanismos de cooperação. Mesmo assim, em algumas áreas, os consórcios desenvolveram-se mais, como em meio ambiente e na saúde, porém ainda em uma proporção insuficiente para a dinâmica dos problemas intermunicipais. Ao invés de uma visão cooperativa, predomina um jogo em que os municípios concorrem entre si pelo dinheiro público de outros níveis de governo, lutam predatoriamente por investimentos privados e, ainda, muitas vezes repassam custos a outros entes, como é o caso de muitas prefeituras que compram ambulâncias para que seus moradores utilizem os hospitais de 
outros municípios, sem que seja feita uma cotização para pagar as despesas. Nesse aspecto, a questão da coordenação federativa é chave.

Outro fenômeno que marcou o processo de descentralização foi a intensa metropolização do país. Não só houve um crescimento das áreas metropolitanas, em número de pessoas e de organizações administrativas, como também os problemas sociais cresceram gigantescamente nesses lugares. No entanto, a estrutura financeira e político-jurídica instituída pela Constituição de 1988 não favorece o equacionamento dessa questão. No que se refere ao primeiro aspecto, a opção dos constituintes foi por um sistema de repartição de rendas intergovernamentais com viés fortemente antimetropolitano, favorecendo inclusive a multiplicação de pequenas cidades (REZENDE, 2001). No que tange ao segundo ponto, o fato é que as regiões metropolitanas (RMs) enfraqueceram-se institucionalmente em comparação com a dimensão que tinham no regime militar. Prevaleceu o municipalismo em detrimento das formas compartilhadas de gestão territorial. É dessa concepção que se originou a explosão dos problemas dos grandes centros urbanos brasileiros.

A quarta característica da descentralização é a sobrevivência de resquícios culturais e políticos anti-republicanos no plano local. A despeito dos avanços que houve, que foram muitos se os enxergarmos de uma perspectiva histórica, diversas municipalidades do país ainda são governadas sob o registro oligárquico, em oposição ao modo poliárquico que é fundamental para a combinação entre descentralização e democracia.

É claro que a única maneira de democratizar e republicanizar o poder local é continuar na trilha da descentralização. Porém, se não houver reformas das instituições políticas subnacionais, além de uma mudança da postura da sociedade em relação aos governantes, o processo descentralizador não leva necessariamente à democracia.

No plano intergovernamental, não se constituiu uma coordenação capaz de estimular a descentralização ao longo da redemocratização. $\mathrm{Na}$ relação dos municípios com os estados, predominava a lógica de cooptação das elites locais, típica do ultrapresidencialismo estadual. Adicionalmente, as unidades estaduais ficaram, com a Constituição de 1988, em um quadro de indefinição de suas competências e da maneira como se relacio- nariam com os outros níveis de governo. Esse vazio institucional favoreceu uma posição "flexível" dos governos estaduais: quando as políticas tinham financiamento da União, eles procuravam participar; caso contrário, eximiam-se de atuar ou repassavam as atribuições para os governos locais.

O avanço da descentralização encontrou a União em uma postura defensiva. Ao perder recursos tributários na Constituição e responsabilizar-se integralmente, em um primeiro momento, pela estabilidade econômica, o governo federal procurou transformar a descentralização em um jogo de mero repasse de funções, intitulado à época de "operação desmonte".

Ao contrário do que o ideário centralista defendeu junto à opinião pública, grande parcela dos encargos foi, sim, assumida pelos municípios. Mas isso aconteceu de modo desorganizado na maioria das políticas - a grande exceção foi a área de saúde. Ademais, a inflação crônica tornava mais instável o repasse de recursos, dificultando uma assunção programada das atribuições por parte dos governos locais. Criou-se, em suma, uma situação de incerteza, de decisões e transferências de verbas em ritmos inconstantes e de ausência de mecanismos que garantissem a cooperação e a confiança mútua.

Aqui se encontra a nova questão resultante do federalismo conformado na redemocratização: a descentralização depende agora, diversamente do que ocorria no regime centralizador e autoritário, da adesão dos níveis de governo estadual e municipal. Por isso, o jogo federativo depende hoje de barganhas, negociações, coalizões e induções das esferas superiores de poder, como é natural em uma federação democrática. Em suma, seu sucesso associa-se a processos de coordenação intergovernamental.

O principal problema da descentralização ao longo da redemocratização foi a conformação de um federalismo compartimentalizado, em que cada nível de governo procurava encontrar o seu papel específico e não havia incentivos para o compartilhamento de tarefas e a atuação consorciada. Disso decorre também um jogo de empurra entre as esferas de governo. O federalismo compartimentalizado é mais perverso no terreno das políticas públicas, já que em uma federação, como bem mostrou Paul Pierson, o entrelaçamento dos níveis de governo é a regra básica na produ- 
ção e gerenciamento de programas públicos, especialmente na área social. A experiência internacional caminha nesse sentido.

Problemas vinculados ao estadualismo predatório e à falta de coordenação da descentralização foram atacados pelo governo Fernando Henrique Cardoso, com sucessos diferenciados, maiores na primeira questão, mais irregulares na segunda. Antes de analisar as políticas em si, é preciso compreender as condições que permitiram as mudanças, bem como as que ainda criam obstáculos para a melhoria da coordenação federativa.

\section{FEDERALISMO SOB FHC: PRINCIPAIS MU- DANÇAS}

A "Era do Real" marca o início da crise do federalismo estadualista, embora não tenha conseguido eliminar todas as suas características predatórias - uma delas, a guerra fiscal, até aumentou de intensidade. Entende-se aqui o Real de uma forma mais ampla do que um plano de estabilização: o contexto que o proporcionou e os seus diversos resultados foram fundamentais para fortalecer o governo federal e enfraquecer os governos estaduais, mudando a dinâmica intergovernamental.

Nesse sentido, a "Era do Real" nasceu antes da promulgação do plano de estabilização. A partir de 1993 e, mais especificamente, da indicação do Ministro Fernando Henrique Cardoso para o Ministério da Fazenda, o governo federal fortaleceuse em razão dos seguintes fatores:

a) o primeiro foi a mudança no cenário externo. Depois de uma década em que se combinaram, perversamente, a redução drástica de empréstimos e refinanciamento externos com uma enorme transferência líquida de recursos para o estrangeiro (SALLUM JÚNIOR, 1999, p. 25), a partir de 1991 começou a ocorrer uma reversão desse processo. Entre 1992 e 1997 ocorreu o auge do fluxo de capitais para a América Latina. De acordo com dados da Comissão Econômica para a América Latina e o Caribe (Cepal), somente o montante de investimento estrangeiro direto passou de US\$ 10 bilhões, em 1990, para US\$ 68 bilhões, em 1997 (GAZETA MERCANTIL, 2000, p. A-20). Soma-se a isso a bem-sucedida renegociação da dívida externa realizada em 1993 e que se constituiu, assim, em uma situação extremamente favorável ao poder Executivo federal no plano internacional, antítese do que fôra a década de 1980;

b) um segundo ponto importante foi a melhora das condições das contas públicas federais. Em verdade, a "Era do Real” recebeu “de bandeja” algumas conquistas dos períodos anteriores, como a modernização orçamentária feita no governo Sarney e o crescimento das reservas cambiais obtido pelo Ministro Marcílio Marques Moreira (governo Fernando Collor de Mello). Além disso, desde o governo Itamar Franco houve um aumento progressivo da arrecadação federal. Diretamente, Fernando Henrique Cardoso, então Ministro da Fazenda, atuou de maneira decisiva para a aprovação do Fundo Social de Emergência (FSE), que aumentou os recursos "livres" da União, constituindo a primeira grande vitória federativa da União no campo financeiro desde a aprovação da Emenda Passos Porto, em 1983, quando se iniciou o aprofundamento da descentralização;

c) o impedimento do Presidente Fernando Collor de Mello e a possibilidade da vitória de Lula nas eleições presidenciais de 1994 levaram a um realinhamento do establishment, em suas dimensões política, social e econômica. Os principais caciques regionais e os partidos ou frações partidárias que comandavam importantes setores empresariais e a maioria dos meios de comunicação de massas não estavam dispostos a ter de engolir o "sapo barbudo" nem um novo aventureiro solitário à direita. Havia, então, os primeiros sinais do fortalecimento do governo federal, creditado à atuação de Fernando Henrique Cardoso, que, aliás, pouco a pouco se transformava informalmente em "Primeiro-Ministro" do Presidente Itamar Franco. Com esse cacife e sua virtù na montagem da coligação eleitoral, Fernando Henrique Cardoso conseguiu formar uma grande aliança, que se reforçou com o sucesso do Real;

d) houve também a consolidação de uma mudança ideológica que há anos estava, paulatinamente, ganhando força na sociedade brasileira. Os principais formadores de opinião, a classe média, os meios de comunicação e importantes setores empresariais adotaram a idéia de reformas constitucionais como a salvação do país e foi isso que, somado à estabilização monetária, uniu fortemente o Presidente à sociedade no primeiro mandato, dando grande popularidade 
a Fernando Henrique Cardoso;

e) pela primeira vez desde o início da redemocratização, as eleições presidenciais de 1994 ocorreram concomitantemente ao pleito estadual e à disputa para o Congresso Nacional. Essa "eleição casada" vinculou os congressistas e o Presidente, e mesmo os governadores, ao mesmo manto de legitimidade, ao contrário do que ocorrera antes, quando a Presidência da República era definida em um pleito "solteiro" e os parlamentares elegiam-se tendo como carro-chefe a eleição à governadoria - 0 que contava a favor da atuação dos chefes dos executivos estaduais junto às bancadas de seus estados. Decorreu, daí, um dos fatores do fortalecimento da Presidência da República vis-àvis os governos estaduais;

f) ainda no plano eleitoral, não foi apenas o caráter concomitante da eleição que favoreceu a União no seu relacionamento com os estados. A eleição de 1994 foi marcada por uma outra peculiaridade: em unidades estaduais estratégicas da federação, foram eleitos governadores fiéis ao Presidente e cujas vitórias derivaram do apoio ao Plano Real. Entre esses governadores destacaram-se Marcello Alencar (Rio de Janeiro), Eduardo Azeredo (Minas Gerais), Antônio Britto (Rio Grande do Sul) e mesmo Mário Covas (São Paulo), embora este tivesse maior independência partidária e calibre político. Apesar de ainda existirem importantes conflitos e FHC ter tido sempre de negociar com os governos estaduais, os últimos atuaram bastante afinados com o Palácio do Planalto, concordância federativa que não era obtida desde o governo Geisel e

g) por fim, o fortalecimento do governo federal completou-se e estruturou-se no estupendo êxito inicial do Plano Real, que conseguiu sustentar-se por mais tempo que qualquer outro e, ademais, estabeleceu uma agenda estrutural, em parte continuada hoje pelo governo Lula. A legitimidade do Real garantiu a eleição e a reeleição do Presidente Fernando Henrique Cardoso, bem como um grande apoio de importantes setores da sociedade, dos governadores e da comunidade internacional. Além da legitimidade, a arquitetura do Plano Real praticamente liquidou os mecanismos que os estados detinham anteriormente para produzir, autônoma e predatoriamente, recursos financeiros.
O êxito inicial do Plano Real teve grande impacto sobre a descentralização. A drástica redução da inflação tornou mais estáveis as transferências intergovernamentais, favorecendo a condução do processo descentralizador. Com isso, a União obteve o instrumento que lhe faltava para poder barganhar a passagem de encargos e funções de uma forma mais racional e programada para os governos subnacionais. Foi essa situação que permitiu a formulação de políticas públicas coordenadas como o Fundo de Manutenção e Desenvolvimento do Ensino Fundamental e de Valorização do Magistério (Fundef), que analisaremos adiante.

A "Era do Real" teve o significado de uma "conjuntura crítica”, isto é, de uma grande mudança na posição relativa dos atores políticos e sociais em relação aos instrumentos de poder e às preferências (PIERSON, 2000). A essa modificação na situação dos agentes somou-se a capacidade do Presidente Fernando Henrique Cardoso de montar e manter por um bom tempo uma coalizão capaz de fazer alterações na antiga estrutura, segundo os objetivos determinados por ele. Nesse sentido, trata-se, também, de um "momento maquiaveliano" (POCOCK, 1975), em que a mudança da "fortuna" (condições objetivas, no sentido marxista) realiza seu potencial na virtù do condutor da mudança, que cria uma nova ordem institucional ${ }^{10}$

Ao mesmo tempo em que se fortaleceu o governo federal, os estados entraram em uma séria crise financeira. O estopim disso, sem dúvida alguma, foi o Plano Real. Em primeiro lugar, porque, com o fim da inflação, os governos estaduais deixaram de ganhar a receita provinda do floating, que permitia o adiamento dos pagamentos e o investimento do dinheiro arrecadado no mercado financeiro, possibilitando assim uma elevação artificial dos recursos e uma diminuição igualmente artificial de boa parte das despesas dos governadores.

O Plano Real produziu outro grande impacto nas finanças estaduais com a elevação das taxas

10 Os conceitos de “conjuntura crítica” e "momento maquiaveliano" foram primeiramente utilizados para o caso brasileiro por Eduardo Kugelmas e Lourdes Sola (1999) e, depois, por Maria Rita Loureiro e Fernando Luiz Abrucio (2004). 
de juros, atingindo em cheio as dívidas estaduais, sobretudo no que se refere aos títulos e dívidas dos bancos estaduais. Depois de terem sido o grande instrumento financeiro dos governadores, especialmente na fase áurea do federalismo estadualista, os bancos estaduais entraram em verdadeira bancarrota. Sofreram mais os grandes estados, sendo os casos mais graves o do Banerj (Rio de Janeiro) e, principalmente, o do Banespa (São Paulo). Neste último, estava em sua carteira a própria dívida do estado de São Paulo, a maior dentre as unidades estaduais.

Contou ainda para a crise financeira dos estados a adoção de medidas tributárias centralizadoras. O resultado final foi uma nova recentralização de receitas. Ainda que o Brasil seja um dos países com maior descentralização fiscal em comparação com os países em desenvolvimento e mesmo perante as federações mais consolidadas do mundo, o movimento concentrador foi de fato considerável, por intermédio da elevação das receitas advindas das contribuições sociais e do represamento de parcela dos recursos para transferência aos governos subnacionais.

Os efeitos e o esgotamento do modelo predatório constituíram-se também em elementos decisivos para a crise financeira dos estados. Não se pode, portanto, creditar as causas do desequilíbrio das contas públicas estaduais apenas às ações e ao fortalecimento do governo federal. Os juros, medidas tributárias centralizadoras, o fim da inflação e a intervenção nos bancos estaduais, sem dúvida, foram fundamentais; porém, são os próprios governos estaduais que têm a maior parcela de culpa na produção de sua crise.

O excessivo gasto com pessoal foi outro grave problema que ajudou a minar as contas públicas estaduais. Esse padrão administrativo foi reforçado pelos estados ao longo da redemocratização, particularmente com a promulgação das constituições estaduais. Nesse tópico, o fator principal no aumento das despesas com funcionalismo adveio da previdência pública, algo crescente em todos os níveis de governo, mas de uma forma mais preocupante no âmbito estadual. Esse diagnóstico demorou para ser feito tanto pelos governadores como pela União, com efeitos deletérios para a reforma do Estado planejada pelo governo Fernando Henrique Cardoso.

O modelo estadualista e predatório enfraqueceu-se sobremaneira com a Presidência de
Fernando Henrique Cardoso, estabelecendo-se uma "conjuntura crítica” na federação brasileira. Mesmo com a corrosão gradativa da coalizão governista no segundo mandato (COUTO \& ABRUCIO, 2004), não houve uma reviravolta na federação e, ao contrário, a adoção de um novo modelo financeiro ganhou força com a aprovação da Lei de Responsabilidade Fiscal (LRF), com apoio considerável dos congressistas, da sociedade e dos governantes locais.

Um balanço geral dos anos FHC mostra que, em parte, ele conseguiu constituir um "momento maquiaveliano" no jogo federativo, tendo a virtù para criar uma nova ordem; em outros aspectos, todavia, isso não foi feito, permanecendo o legado do federalismo desenvolvido durante a redemocratização e ainda com algumas influências da trajetória histórica das relações intergovernamentais do país. Analisaremos a seguir como se deu, sob esse pano de fundo, o processo de coordenação federativa no período 19952002.

\section{COORDENAÇÃO FEDERATIVA NA ERA} FHC: AVANÇOS, DILEMAS E PROBLEMAS

Durante os dois mandatos de Fernando Henrique Cardoso, podemos destacar sete mecanismos gerais adotados pelo governo federal para modificar e coordenar as relações intergovernamentais e o processo de descentralização. O primeiro deles refere-se ao fato de que o Brasil tinha iniciado o processo descentralizador antes de estabilizar a economia, o que tornou mais difícil a constituição de jogos mais coordenados e efetivos de divisão de atribuições, sobretudo porque a inconstância da transferência das verbas constitui um obstáculo em uma federação desigual como a brasileira. Ao reduzir a inflação, houve um impacto positivo para a regularização dos repasses de recursos aos governos subnacionais. Isso permitiu a abertura de uma nova rodada de negociação para (re)pactuar a descentralização em diversas políticas públicas.

Um segundo mecanismo foi a associação entre a descentralização e os objetivos de reformulação do Estado. Nesse sentido, o governo federal procurou, em primeiro lugar, reduzir todos os focos de criação de déficit público nos governos subnacionais, especialmente os de cunho predatório - isto é, que repassavam custos para a União. Para alcançar essas metas fiscais, houve uma atuação conjunta em prol da moderni- 
zação da estrutura fazendária em vários estados com recursos de instituições internacionais - e, no segundo mandato, a aprovação de uma regra federativa de restrição orçamentária - a Lei de Responsabilidade Fiscal -, além da adoção de medidas de auxílio na área previdenciária.

O modelo de coordenação federativa no campo da reformulação estatal, ademais, incluiu a proposição de programas de demissão voluntária aos estados, com financiamento federal. Em um sentido mais institucional, o Ministério da Administração e Reforma do Estado (MARE) procurou ativar o Fórum dos Secretários Estaduais de Administração, realizando reuniões mais constantes e cujo tema de debate era a modernização das máquinas públicas - isso durou apenas os primeiros quatro anos do período FHC. Por fim, destaca-se aqui o processo de privatização das empresas estaduais, no qual o Banco Nacional de Desenvolvimento Econômico e Social (Bndes) teve um papel decisivo.

O repasse de recursos condicionado à participação e à fiscalização da sociedade local foi um terceiro mecanismo marcante dos anos FHC. De certo modo, houve uma continuidade da estratégia já prevista pela Constituição de 1988, particularmente na criação e ampliação do escopo dos conselhos de políticas públicas. Aprofundou-se essa concepção com a determinação de que certas transferências só seriam recebidas se existissem os Conselhos da área em questão. Além disso, o programa Comunidade Solidária optou pela produção de programas intrinsecamente vinculados à montagem de parcerias entre o Estado e a sociedade. O caráter democrático da descentralização, mais do que o aspecto fiscal, foi a tônica dessa política.

A coordenação de políticas públicas foi muito importante nas áreas de saúde e educação, com o PAB (Piso de Atenção Básica) e o Fundef, respectivamente. Os mecanismos coordenadores aqui utilizados passaram pela combinação de repasse de recursos com o cumprimento de metas préestabelecidas ou a adoção de programas formulados para todo o território nacional. Trata-se de um modelo indutivo que transfere verbas segundo metas ou políticas-padrão estipuladas nacionalmente, procurando assim dar um perfil mais programado e uniforme à descentralização, sem retirar a autonomia dos governos subnacionais em termos de gestão pública. No caso do Fundef, ocorreu ainda uma redistribuição horizontal de recursos, experiência inédita na federação brasileira.

A partir do final do primeiro mandato e início do segundo, foram adotadas políticas de distribuição de renda direta à população. $\mathrm{O}$ primeiro deles foi o PETI (Programa de Erradicação do Trabalho Infantil), depois veio o Programa Renda Mínima e, mais adiante o Programa Bolsa-Escola, a que se juntaram os programas Bolsa-Alimentação e o Vale-Gás. Buscou-se, com tais medidas, atacar diretamente a pobreza por meio de políticas nacionais, as quais podem ser realizadas em parceria com outros instrumentos de gestão local, mas com a garantia de uma verba federal padronizada. O pressuposto dessas ações era que em problemas de origem redistributiva, particularmente em uma federação, é necessária a atuação do governo federal para evitar o agravamento das desigualdades.

A aprovação de leis ou mudanças constitucionais atinentes à temática federativa foi outro mecanismo bastante utilizado nos anos FHC. Com tais ações, ficou claro que o objetivo era fazer uma reforma institucional no federalismo brasileiro, mais do que implementar políticas de governo, embora o padrão de implementação dessas medidas não seja completamente coerente, além de responder a pressões políticas diferenciadas dentro do poder Executivo federal. Das 34 emendas constitucionais aprovadas de 1995 até junho de 2002, quinze delas afetavam diretamente o pacto federativo. Isso ocorreu nos seguintes terrenos:

a) no tributário, com a aprovação duas vezes do Fundo de Estabilização Fiscal (FEF) e sua renovação posterior pela Desvinculação de Receitas da União (DRU), como também pelas mudanças nas contribuições sociais, especialmente aquelas vinculadas à criação e à prorrogação da Contribuição Provisória sobre Movimentações Financeiras (CPMF). Foi por meio das Contribuições Sociais que a União aumentou suas receitas, sem precisar reparti-las com os outros níveis de governo. Também foram feitas modificações constitucionais que atingiram o Imposto Predial e Territorial Urbano (IPTU), garantindo sua progressividade, e no Imposto sobre Serviços (ISS), procurando efetuar aqui uma harmonização tributária entre os municípios; 
b) na organização político-administrativa, com a aprovação da "Emenda Jobim” (Emenda Constitucional n. 15), que tornou mais difícil a criação de municípios, com a aprovação de novos limites de gastos dos legislativos locais (Emenda Constitucional n. 25) e mesmo com a instituição da reeleição (Emenda Constitucional n. 16). Pouco se comentou acerca do impacto federativo da reeleição, mas o fato é que ela alterou o mercado político brasileiro e provavelmente terá um grande impacto sobre os padrões de carreira tradicionais da classe política, que antes passavam pela utilização dos legislativos, sobretudo a Assembléia Legislativa, como trampolim para postos executivos;

c) na reforma do Estado, com a abertura à competição e à privatização nas áreas do gás canalizado e das telecomunicações, e a reformulação de vários artigos referentes à administração pública (Emenda Constitucional n. 19) e à previdência (Emenda Constitucional n. 20), com impacto enorme sobre a gestão governamental dos estados e municípios. Não por acaso, todas essas medidas passaram por intensas negociações com prefeitos e, sobretudo, governadores (Cf. ABRUCIO \& COSTA, 1999; MELO, 2002) e

d) na área social, com a aprovação do Fundef (Emenda Constitucional n. 14), da chamada "PEC [Proposta de Emenda Constitucional] da Saúde” (Emenda Constitucional n. 29) e do Fundo de Combate e Erradicação da Pobreza (Emenda Constitucional n. 31), que ajudou a modificar o padrão das políticas de distribuição de renda direta à população, tal como referido anteriormente. É interessante notar que tais reformulações constitucionais criam obrigações válidas não só para os próximos Presidentes, mas também para os futuros governantes de estados e municípios.

Além das alterações constitucionais, várias leis complementares e ordinárias com impacto federativo foram aprovadas. Destacam-se a Lei de Responsabilidade Fiscal e a Lei Kandir, que transformaram regras básicas das finanças públicas. Na verdade, essa nova legislação reordenou os parâmetros de ação dos entes subnacionais, criando as condições para que as relações intergovernamentais ganhem um sentido diferente do constituído na redemocratização, especificamente no que tange à convivência mais respon- sável entre os níveis de governo.

A avaliação de políticas descentralizadas também entrou na agenda de coordenação federativa do governo FHC. O Ministério da Educação (MEC) constituiu-se no principal agente dessa mudança, criando sistemas avaliadores que apresentam regularmente os resultados alcançados por essa política. Entretanto, esse vetor avaliador não se tornou uma regra geral do governo federal.

Em resumo, o governo FHC usou principalmente sete mecanismos de ação na ordem federativa: 1) o combate à inflação e a respectiva regularização dos repasses, permitindo uma negociação mais estável e planejada com os outros entes; 2) a associação dos objetivos da reforma do Estado, como o ajuste fiscal e a modernização administrativa, com a descentralização; 3) condicionou a transferência de recursos à participação da sociedade na gestão local; 4) criou formas de coordenação nacional das políticas sociais, baseadas na indução dos governos subnacionais a assumirem encargos, mediante distribuição de verbas, cumprimento de metas e medidas de punição, também normalmente vinculadas à questão financeira, além de utilizar instrumentos de redistribuição horizontal no Fundef; 5) adoção de políticas de distribuição de renda direta à população, partindo do pressuposto de que o problema redistributivo não se resolveria apenas com ações dos governos locais, dependendo do aporte da União; 6) aprovou um conjunto enorme de leis e emendas constitucionais, institucionalizando as mudanças feitas na federação, dando-lhes, assim, maior força em relação às pressões conjunturais e 7) estabeleceu instrumentos de avaliação das políticas realizadas no nível descentralizado, especialmente na área educacional.

Entretanto, o modelo federativo adotado pelo governo Fernando Henrique Cardoso também teve problemas gerais de funcionamento. Entre eles, estão a fragmentação de uma mesma política em vários órgãos e ministérios, como é o caso do saneamento básico; a pulverização das políticas de renda, a despeito da ação coordenadora do Projeto Alvorada; a falta de uma avaliação consistente na maior parte das áreas descentralizadas; a existência de poucos ou fracos fóruns intergovernamentais, a partir dos quais as políticas nacionais poderiam ser melhor controladas e legitimadas; a adoção de uma visão tributária perversa do ponto de vista federativo, seja pela 
recentralização de recursos, seja pela negligência em relação à harmonização tributária do Imposto sobre Circulação de Mercadorias e Serviços (ICMS); a deterioração das políticas regionais, levada às últimas conseqüências com o fim da Superintendência para o Desenvolvimento da Amazônia (Sudam) e da Superintendência para o Desenvolvimento do Nordeste (Sudene) e o fracasso das políticas urbanas, afetando setores como habitação, saneamento, segurança pública e transportes metropolitanos.

Pretende-se, a seguir, fazer um breve relato de três áreas de coordenação federativa contempladas nos anos FHC. O propósito não é avaliar substantivamente tais ações; o intuito desta parte do trabalho é entender do papel do governo federal em tais questões ou setores.

\section{V.1. Reforma do Estado: questões financeiras e} administrativas

O tema central da agenda federativa de FHC foi a questão financeiro-fiscal. Suas ações nortearam-se pelos objetivos de acabar com os mecanismos que os governos subnacionais tinham de repassar custos à União, pela criação de condições para que os estados conseguissem ajustar suas contas e pelo programa de privatização da empresas estaduais, pelo qual procuraram, ao mesmo tempo, remodelar setores econômicos segundo o modelo de Estado defendido por Brasília e obter recursos para quitar a dívida pública. Além disso, o segundo período governamental concentrou-se, movido ainda pela ótica econômica, na questão previdenciária.

No plano financeiro-fiscal, o governo federal aproveitou a enorme crise que assolou os governos estaduais e a legitimidade da "Era do Real" para, primeiramente, reestruturar o sistema bancário estadual. $\mathrm{O}$ resultado final apontou para o fim das formas de repasse de custos ao Banco Central, por meio da extinção, privatização e federalização da grande maioria dos bancos estaduais. Se, por um lado, este processo pôs fim a um mecanismo estrutural de produção de déficit, por outro lado ele teve um preço para os cofres da União, causado por dois fatores: pela dificuldade em resolver a situação do Banespa, que postergou a resolução dos problemas de todo o sistema, e pela necessidade de criar-se um instrumento financeiro de transição, o Proes (Programa de Incentivo à Redução do Setor Público Estadual na Atividade Bancária), cujo custo final, em valores de março de 2002, foi de R $\$ 70$ bilhões (MORA, 2000). Não obstante, esse modelo permitiu uma mudança crucial na lógica das relações intergovernamentais.

O governo federal, por meio principalmente do Bndes, também atuou fortemente no programa de privatizações dos estados. O objetivo, como dito acima, era reestruturar a ação do Estado em áreas estratégicas e obter recursos para quitar a dívida pública. No primeiro mandato de FHC, foram privatizadas 24 empresas estaduais e em mais 13 ocorreu a venda de participação acionária, o que significou a obtenção de $37 \%$ dos quase US\$ 70 bilhões movimentados por todas as privatizações e concessões realizadas no período, excluídas as transferências de dívidas (ABRUCIO \& COSTA, 1999, p. 101).

O êxito financeiro e programático alcançado pelo poder Executivo federal nas privatizações nos estados não solucionou todos os problemas envolvidos nesse tema. Primeiro porque muitos estados usaram parte das receitas obtidas não para o pagamento de suas dívidas com a União, mas para gastos correntes. É claro que houve um ganho importante em termos de abatimento de débito, mas sem, no entanto, levar a maioria dos estados à realização de um verdadeiro ajuste estrutural das contas públicas - os poucos que conseguiram fazê-lo, como São Paulo, precisaram fazer cortes e racionalização dos gastos, bem como aumentar a receita.

Mais do que isso: a política macro-econômica adotada no primeiro mandato de FHC dificultou qualquer ajuste provindo apenas dos recursos de privatização. Isso porque o modelo da sobrevalorização cambial e sua aposta no financiamento por poupança externa vincularam-se a uma taxa alta de juros que, ao fim e ao cabo, elevava ainda mais a dívida pública, de modo que os recursos obtidos com a venda das empresas (estaduais e federais) acabavam, em boa medida, indo "para o ralo". Em termos estruturais, os governadores teriam feito melhor se utilizassem a receita da privatização para capitalização de fundos de pensão do funcionalismo estadual, com efeitos benéficos maiores no curto e longo prazos. Mas, naquele momento, os governos estaduais e o governo federal, no seu papel de coordenação federativa, não tinham idéia do impacto estrutural dos gastos previdenciários às contas públicas subnacionais.

Obviamente que as privatizações são funda- 
mentais para diminuir redes clientelistas estabelecidas entre as empresas estatais, a classe política e as empresas privadas, constituindo-se assim em um aspecto essencial para mudar a gramática política brasileira (NUNES, 1997). Ademais, sem as empresas estatais, os estados tendem a não fazer determinados gastos que levariam ao aumento de seu déficit. Colocados esses aspectos positivos à mesa, deve-se ter cuidado para não transformar o programa de privatizações em uma ação a partir da qual o Estado sai dessas esferas econômicas.

Aqui se encontra o maior problema do programa de privatizações dos estados sob a coordenação federativa da União: não se propôs, na grande maioria dos casos, um modelo regulatório consistente para o dia seguinte da reforma do Estado. Do mesmo modo que o Bndes prestou adequada assessoria financeira para a venda das empresas estaduais, também seria necessária a ajuda na criação de agências regulatórias - montadas depois em número menor de estados do que o universo de governadorias que privatizaram empresas (ABRUCIO, 2004). Porém, nesse aspecto, pesou mais o lado da primeira onda de reformas voltadas para o mercado do que o aspecto essencial da segunda rodada de reformas, de criação de novas instituições estatais voltadas à regulação econômica (BANCO MUNDIAL, 1997).

A renegociação das dívidas dos estados, por meio da Lei n. 9 496/97, foi um passo importante para disciplinar as relações federativas, rompendo com o antigo modelo predatório. Em primeiro lugar, o acordo contemplou quase a totalidade das unidades estaduais, evitando-se assim a existência de free riders ${ }^{11}$. No total, ela refinanciou um montante de R\$ 132 bilhões. Em segundo lugar, embora os estados reclamem hoje da porcentagem da receita líquida que têm de dispor, o fato é que receberam um grande subsídio da União, a partir do qual houve uma redução substantiva das taxas de juros que vinham pagando antes. Esse novo contrato, ademais, é bem diferente dos efetuados ao longo da redemocratização, particularmente pela sua capacidade de fazer que seja de fato cumprido, incluindo a retenção de transferências federais - o único estado que tentou burlar essa regra, Minas Gerais, na gestão de Itamar

11 “Caronistas” (N. R.).
Franco, teve verbas bloqueadas e logo a seguir regularizou seu pagamento.

As despesas com pessoal nos governos estaduais constituíram mais um tópico da agenda federativa do período FHC. No início de 1995, das 27 unidades estaduais (contando o Distrito Federal), apenas seis despendiam menos de $60 \%$ da receita líquida com o funcionalismo, sendo que em três delas (Roraima, Amapá e Tocantins) a maior parte dos servidores ainda era paga pela União, já que a sua condição de estado é bastante recente. A continuidade desse problema dificultará a resolução dos déficits financeiros da federação.

Por isso, o governo federal resolveu atuar nessa questão. A medida de maior impacto inicial foram os programas de Demissão Voluntária (PDVs). Com financiamento da Caixa Econômica Federal, os PDVs resultaram na demissão de 100 mil funcionários públicos estaduais, mas tiveram pequeno impacto na redução de custos, de apenas 4,5\% do que se gastava com pessoal ativo - os estados com maior contingente de servidores, ademais, foram os menos afetados (BELTRÃO, ABRUCIO \& LOUREIRO, 1998).

Foram constatados dois grandes problemas na aplicação dos PDVs. O primeiro é que os servidores que aderiam a esses programas de dispensas normalmente tinham uma melhor qualificação profissional, ficando os com menor capacidade gerencial. Além disso, em muitos estados não havia um mapa preciso do perfil do funcionalismo e, desse modo, não se sabia exatamente quais eram os gargalos burocráticos. Faltou aqui uma ação mais coordenada entre o governo federal e as administrações subnacionais.

A falta de uma coordenação federativa também levou a um diagnóstico equivocado quanto aos gastos com pessoal. O governo FHC insistiu, por boa parte do primeiro mandato, em um argumento: a resolução do problema dar-se-ia com a permissão de dispensa de funcionários quando um nível de governo gastasse mais do que $60 \%$ da receita líquida com folha de pagamento. Ao não discriminar os gastos entre os poderes, a então Lei Camata colocou para o governador uma tarefa em que em parte ele não podia atuar. Isso porque cresciam, cada vez mais, os gastos com pessoal do poder Legislativo e, sobretudo, do poder Judiciário. Mas o maior erro foi outro: não perceber que o maior problema do excesso de gastos 
com pessoal provinha do pagamento de inativos. Novamente, isso não foi detectado porque faltava uma burocracia competente nos estados e uma ação coordenadora do governo federal para detectar essa questão. Somente no final de 1997 é que os governos estaduais e a União deram-se conta da magnitude desse problema.

Mesmo tendo adquirido poder no pêndulo federativo no primeiro mandato, a União não se preparou adequadamente para atuar como agente coordenador no plano intergovernamental. Deveria ter havido orientação e capacitação da burocracia federal para recolher informações dos governos subnacionais ou então, em uma via mais pertinente para o federalismo, os estados e os municípios poder ter sido auxiliados na construção de capacidades institucionais. Em vez disso, o primeiro governo FHC procurou "vender" uma receita de reforma do Estado sem estabelecer uma rede da burocracia nacional com as estaduais e municipais.

Houve, porém, dois avanços no segundo mandato de Fernando Henrique Cardoso. O Ministério da Previdência e Assistência Social assumiu uma importante função coordenadora e atuou decisivamente na assessoria e indução dos estados e municípios. O resultado é que mais e mais governos subnacionais estão constituindo Fundos Previdenciários, com cálculos atuariais mais precisos - mas a tarefa teria sido mais fácil se o dinheiro da privatização fosse usado inicialmente na capitalização desses sistemas.

O aprendizado federativo também foi constatado na definição de gastos com pessoal e nos instrumentos de controle com a promulgação da Lei de Responsabilidade Fiscal (LRF), em maio de 2000. A LRF definiu melhor os mecanismos de restrição orçamentária, responsabilizando mais claramente todos os poderes. Adicionalmente, suas regras estabeleceram instrumentos de enforcement mais efetivos, que dificultam uma postura contrária à nova regulamentação, por conta das penalidades. E, ainda, o governo federal exerceu um papel coordenador ativo por intermédio do Bndes, que assessorou governos locais, disseminou as noções básicas da LRF por todo o país e deu incentivos para a modernização da máquina administrativa dos governos subnacionais, com vistas a cumprir os requisitos fiscais básicos.

A LRF foi uma das experiências mais bem- sucedidas de coordenação federativa nos anos FHC. Faltou, no entanto, criar um fórum de discussão entre os vários níveis de governo, tal como estabelecido no artigo 67 da LRF, que estipula a instituição de um Conselho de Gestão Fiscal. O governo FHC não se mobilizou politicamente para regulamentar tal Conselho, causando prejuízo para a democratização da federação. No fundo, prevaleceu aqui a visão da equipe econômica, que supõe, seguindo certas versões do federalismo fiscal, que deve haver uma hierarquização entre os entes governamentais, com o governo federal que nesse caso poderia chamar-se governo central - comandando linearmente as finanças públicas. Nada mais distante da soberania compartilhada que marca o federalismo.

A melhoria das condições fiscais de longo prazo, por fim, tem a ver com duas outras variáveis, praticamente negligenciadas no período FHC: a realização de reformas institucionais e a construção de um novo modelo de desenvolvimento. No primeiro aspecto, é importante que sejam realizadas mudanças no relacionamento entre a sociedade e o Estado e das instituições políticas subnacionais, especialmente do Tribunal de Contas e do poder Judiciário, para aumentar a accountability democrática. Além disso, a burocracia dos níveis subnacionais precisa ser continuamente aperfeiçoada.

A construção de um novo modelo de desenvolvimento que melhore a situação dos estados depende basicamente de ações nacionais. Por um lado, é preciso atacar as desigualdades regionais, que impedem a obtenção de resultados satisfatórios em várias partes do país. Por outro, a guerra fiscal não pode mais continuar, pois ela cria déficits futuros aos governos estaduais e, efetivamente, não resolve o problema do desenvolvimento; ao invés disso, acirra o conflito horizontal entre as unidades federativas.

Desse modo, a resolução federativa dessa questão passa, sim, pela continuidade da trilha aberta pela Lei de Responsabilidade Fiscal, com a ativação de um fórum federativo que a gerencie mais democraticamente, mas também depende de reformas estruturais - criação ou fortalecimento dos fundos previdenciários, modernização das burocracias estaduais, democratização das instituições políticas subnacionais e novo modelo de desenvolvimento - para as quais o fiscalismo reinante nos anos FHC deu pouca atenção. 
V.2. Coordenação federativa na área social: alguns exemplos

A área de proteção social é bastante abrangente e difícil de ser mapeada no espaço deste artigo. Por essa razão, escolhemos três de suas políticas, analisando como se deu a relação entre descentralização e coordenação federativa, sem fazer uma avaliação substantiva dos resultados alcançados.

A saúde é, sem dúvida alguma, a política pública de maior destaque no quadro federativo desde a Constituição de 1988. O modelo de descentralização proposto foi construído por muitos anos de lutas contra a centralização dos programas e da gestão dos recursos, com destaque para a atuação de sanitaristas e profissionais da área médica que constituíram, junto com lideranças locais e movimentos sociais, aquilo que alguns denominam de "partido da saúde" - a que hoje se somam a burocracia setorial e diversos políticos, muitos com origem na área.

A reforma desse setor aprofundou-se com a Constituição de 1988 e o estabelecimento do Sistema Único de Saúde, o SUS. Seus critérios básicos são a universalidade, a integralidade e a igualdade de assistência garantida a todos os brasileiros; preconizava ainda a descentralização da gestão do sistema e a participação da comunidade, com um tom fortemente municipalista.

Na década de 1990, surgiram também as NOBs (Normas Operativas Básicas), que representaram um esforço de racionalização dos repasses de recursos e dos gastos pelos estados e municípios, além da criação de instrumentos de fiscalização e avaliação das políticas de saúde. Elas tentavam definir, com a maior clareza possível, os custos e benefícios resultantes do cumprimento ou não das regras e critérios de repasse de recursos (principalmente no que se refere às condições necessárias e suficientes ao repasse de recursos financeiros entre União, estados e municípios), prestação de contas e acompanhamentos das ações de saúde.

A partir da NOB-96, o SUS procurou estruturar-se pela responsabilização de cada instância de governo. Estabeleceu-se que os gestores federal e estadual são os promotores da harmonização, modernização e integração do SUS. Essa tarefa acontece, especialmente, na Comissão Intergestores Bipartite (CIB), no âmbito esta- dual, e na Comissão Intergestores Tripartite (CIT) no âmbito nacional. A NOB-96 estimula as parcerias entre municípios, mas não cria incentivos financeiros específicos (ABRUCIO \& COSTA, 1999, p. 78).

Foi nesse contexto de maior consistência da descentralização que o governo FHC estabeleceu suas políticas de saúde. Os problemas iniciais estavam vinculados mais à regularidade dos repasses e à garantia de fonte seguras e permanentes de recursos. Com a resolução destes últimos, a partir do fim da inflação e da aprovação da CPMF com recursos “carimbados” para a saúde, a descentralização aprofundou-se ainda mais. Entre 1995 e 1999, sem contabilizar as transferências, os gastos dos níveis de governo eram de 58\% para a União, $16 \%$ para os estados e $26 \%$ para os municípios; após contabilizarmos as transferências, as cifras mudam substancialmente: $23 \%$ para a União, 25\% para os estados e 52\% para os municípios. Além disso, segundo dados de dezembro de 2001, 99\% dos municípios estavam habilitados a uma das condições de gestão, sendo 89\% em Gestão Plena da Atenção Básica, e 10,1\% na Gestão Plena do Sistema Municipal (MELO, 2002, p. 4).

No campo da saúde, a descentralização e a coordenação federativa estiveram presentes em três questões. A primeira diz respeito ao fortalecimento das atividades intrinsecamente nacionais. A primeira delas é a organização administrativa do Ministério da Saúde, que se reforçou com a melhoria dos sistemas de informação, em especial o Datasus. Houve também uma reorganização administrativa, com aperfeiçoamento de pessoal e constituição de duas agências reguladoras essenciais: a Agência Nacional de Vigilância Sanitária (Anvisa) e a Agência Nacional de Saúde Suplementar (ANS). Cabe reforçar que a coordenação federativa associa-se claramente à capacidade burocrática do governo federal.

A política de saúde do governo FHC adotou iniciativas para reforçar as funções redistributivas do SUS, orientando recursos para as regiões mais pobres e menos populosas (COSTA, SILVA \& RIBEIRO, 1999). A principal medida nesse sentido foi a criação, em dezembro de 1997, do PAB. Ao mesmo tempo em que procura reduzir as desigualdades de recursos, o PAB também funciona como incentivo à municipalização, pois somente os governos locais habilitados podem receber tais 
recursos.

O PAB é composto de uma parte fixa e outra variável. A primeira destina-se à atenção básica da saúde e garante a transferência automática, fundo a fundo, de um mínimo de R\$ 10 por habitante/ ano para todos os municípios brasileiros. A idéia era reduzir as desigualdades existentes entre as municipalidades, uma vez que aquelas com maior “capacidade produtiva” tendiam a receber mais recursos, ao passo que as pequenas, com rede incipiente ou nenhuma rede de atenção à saúde, pouco recebiam. A parte variável do PAB é uma das invenções mais frutíferas do federalismo nos anos FHC. Sua distribuição de recursos só ocorria se os governos locais aderissem aos programas nacionais definidos como prioritários. Além disso, para receber tais recursos era preciso passar por todo o sistema de conselhos, que procura fiscalizar o uso adequado dos recursos públicos.

Foram seis os programas nacionais incluídos no PAB variável: Saúde da Família-Agentes Comunitários de Saúde, Saúde Bucal, Assistência Financeira Básica, Combate às Carências Nutricionais, Combate a Endemias e Vigilância Sanitária. A característica básica dessas políticas era a ênfase na prevenção e não na cura, lema histórico do movimento sanitarista. O município podia aderir a quantos quisesse e recebia os recursos de acordo com o estipulado em cada programa. Tais ações governamentais, ademais, envolvem capacitação dos gestores locais e a avaliação dos resultados, seja pelo sistema federal, seja pelo controle social ligado aos mecanismos de accountability intrínsecos ao SUS. Os resultados foram bastante satisfatórios no que se refere à adesão e, conseqüentemente, ao número de pessoas atingidas. No caso do Programa de Agentes Comunitários de Saúde (PACS), por exemplo, houve um aumento de $30 \%$ na população coberta entre 1994 e 1998 (SINGER, 2002, p. 517).

A terceira medida foi a aprovação da chamada "PEC da Saúde” (Emenda Constitucional n. 29), que determinou a elevação gradativa da porcentagem de recursos destinados a essa área nos três níveis de governo. Com isso, o problema que o governo Fernando Henrique Cardoso encontrou no início do seu primeiro mandato de instabilidade nos gastos com saúde foi, em boa medida, resolvido. Muitos criticam o modelo da vinculação, pois ele “engessa” mais o orçamento e os próprios governantes, que devem subordinar sua agen- da eleitoral vencedora a tais dispositivos constitucionais. Talvez tivéssemos de combinar melhor as regras intertemporais que orientam a ação dos entes federativos com mecanismos de negociação contínua de metas e resultados - e, nesse sentido, o Fundef está mais adequado ao padrão federalista de políticas públicas, uma vez que tem metas e prazo para esgotar-se, ao mesmo tempo em que suas diretrizes ultrapassam o período de mais de um governante.

Não foram equacionadas todas as questões federativas ligadas à saúde. A coordenação intergovernamental, a despeito da força integradora do SUS e do “partido da saúde”, vez ou outra revela sua fragilidade, como ficou bem claro no episódio da dengue, em 2002, em que a briga dos governantes era para saber se o mosquito era municipal, estadual ou federal. A maior lacuna desse sistema é a indefinição do papel das unidades estaduais. Nesse tópico, o governo federal precisa criar formas de indução à participação e à cooperação da mesma maneira que o PAB fê-lo em relação aos municípios.

O Ministério da Saúde também tentou incentivar a formação de consórcios entre os municípios, como forma de melhorar a prestação do serviço segundo problemas que são regionais e/ou porque a maioria dos governos locais não tem condições de resolver todos os seus problemas nessa área.

O fato é que a saúde é uma das áreas com maior número de consórcios. Em 2000, havia 141 consórcios de saúde, em 13 estados e 1168 municípios e abrangendo uma população de 25362 735 habitantes, segundo estudo da Organização Panamericana de Saúde e do Ministério da Saúde. Trata-se de um dado impressionante comparado ao que acontece nas outras políticas públicas. Porém, os mesmos números mostravam que no bloco das municipalidades que têm entre $10 \mathrm{mil} \mathrm{a}$ 20 mil habitantes a porcentagem de consórcios era de $23,5 \%$, enquanto no estrato que vai de 20 mil a 50 mil, o contingente atingido era de 12,4\%. Além do mais, nenhuma capital tinha consórcio, o que é um absurdo, sabendo que as regiões metropolitanas sofrem freqüentemente do problema do "carona" - habitantes de cidade vizinha que se utilizam dos equipamentos sociais e não pagam nada por isso.

Esse retrato revela que é preciso igualmente ter uma política de indução à criação dos consór- 
cios, na mesma linha do PAB. Mas, nesse caso, há um problema estrutural, revelado anteriormente: o federalismo compartimentalizado, o municipalismo autárquico e a fragilidade jurídica desse instrumento dificultam a adesão a essa união intermunicipal.

Na área de educação, uma política destacouse nos anos FHC como forma de coordenação federativa. Trata-se do Fundo de Manutenção e Desenvolvimento do Ensino Fundamental e de Valorização do Magistério (Fundef). Aprovado pelo Congresso Nacional em 1997, ele obriga os governos a aplicarem $25 \%$ dos recursos resultantes da receita de impostos e transferências na educação, sendo que não menos de $60 \%$ deverão ser destinados ao Ensino Fundamental. Sua implantação, em nível nacional, iniciou-se em $1^{0}$ de janeiro de 1998.

Dos recursos do Fundef, pelo menos 60\% devem ser aplicados na remuneração dos profissionais do magistério em efetivo exercício de suas atividades no Ensino Fundamental público. Ademais, são definidas metas que balizam a ação dos gestores locais. Entre elas, podemos citar que os estados, o Distrito Federal e os municípios devem dispor de um novo Plano de Carreira e Remuneração do Magistério.

O rateio do Fundef é proporcional ao número de alunos matriculados na respectiva rede de ensino. Com isso, a distribuição de recursos obedece a um critério mais justo, vinculado à assunção efetiva de encargos. Ocorre aqui uma adequação melhor das transferências às atribuições, algo fundamental em uma federação, especialmente a nossa, em que a desigualdade e a politização dos critérios foram regularmente empecilhos à efetividade das políticas.

O objetivo do governo federal com o Fundef foi corrigir a má distribuição de recursos entre as diversas regiões e dentro dos próprios estados, diminuindo as desigualdades presentes na rede pública de ensino. Trata-se, nesse sentido, de uma política vertical e horizontal de redistribuição de recursos, o que a faz única no federalismo brasileiro.

Para assegurar o seu cumprimento, a lei exige a criação dos conselhos de Acompanhamento e Controle Social do Fundef, instituídos em cada esfera de governo, que têm por atribuição acompanhar e controlar a repartição, a transferência e a aplicação dos recursos do Fundo. O Conselho Municipal de Acompanhamento e Controle Social do Fundef deve ser composto de, pelo menos, quatro membros, representando a Secretaria $\mathrm{Mu}-$ nicipal de Educação ou órgão equivalente; os professores e diretores das escolas públicas de ensino fundamental; os pais de alunos e os servidores das escolas públicas de ensino fundamental.

Em comparação com a saúde, em que o papel do governo federal sempre foi muito forte, a ação da União na educação foi prejudicada pela forma confusa e movediça de distribuição de responsabilidades e competências. Nessa "torre de Babel”, a União cumpria as tarefas mais variadas, em todos os níveis educacionais, mas não conseguia direcionar a contento seus esforços para o Ensino Fundamental. Desse modo, seu comprometimento era mais voluntarista ou discricionário do que fruto de um plano de cooperação federativa na área educacional. Isso apesar de a Constituição definir expressamente a missão do governo federal: promover prioritariamente a universalização e a eqüidade no ensino público, incentivando, financiando e fornecendo assistência técnica a estados e municípios. O Fundef conseguiu reorganizar com sucesso a ação federal.

Os resultados do Fundef revelam o crescimento tanto do número de alunos matriculados como da municipalização do Ensino Fundamental, tarefas que não avançavam satisfatoriamente no período anterior. Em 1996, antes da implantação do Fundo, $63 \%$ das matrículas estavam na rede estadual, enquanto $37 \%$ estavam no âmbito municipal. Um ano depois de iniciado esse programa, já houve uma reversão significativa: $51 \%$ dos alunos pertenciam ao sistema estadual e $49 \%$, ao municipal. Outro dado revelador da mudança: em 1998 os governos municipais detinham $38,2 \%$ das verbas do Fundef e, em 2000, passaram a reter 43,2\% (GARSON \& ARAÚJO, 2001, p. 2-3).

Em resumo, o Fundef foi bem-sucedido no que se refere à questão federativa por ter melhorado a redistribuição de recursos (em termos verticais e horizontais), aumentado a esperança por simetria entre os níveis de governo, além de impulsionar uma municipalização mais planejada e a colaboração intergovernamental. Contudo, existem dois dilemas federativos não equacionados. O primeiro é o da fragilidade do controle, perceptível pelo enorme crescimento das denúncias de corrupção em vários estados. Para tanto, é ne- 
cessário estabelecer formas articuladas de fiscalização institucional entre o TCU, os tribunais de Contas do plano subnacional, o Conselho vinculado à política e o poder Legislativo.

O Fundef, ademais, não foi montado sobre um aparato institucional capaz de discutir e revisar sua implantação tal qual há na área de saúde, em que a rede federativa é mais forte e legitimadora. Em termos democráticos, é essa rede que permite a continuidade e as alterações da política ao longo do tempo.

Finalizando a discussão de algumas políticas sociais, destacamos as políticas de transferência de renda à população. Iniciado com o PETI, passando pelo mal definido Programa de Renda Mínima até chegar ao bolsa-escola, o governo FHC gastou sete anos de seu mandato para construir uma forma mais efetiva de atacar a pobreza. $\mathrm{Na}$ verdade, ao longo desse aprendizado, percebeuse que problemas redistributivos em uma federação, como já apontaram Paul Peterson (1995) e Paul Pierson (1995), só podem ser resolvidos com a intervenção ativa de políticas nacionais. A maior novidade em termos substantivos é a vinculação da transferência de dinheiro a certos objetivos, como a manutenção da criança na escola e a redução da evasão escolar.

A soma de recursos aí direcionada cresceu bastante, graças à aprovação do Fundo de Combate e Erradicação da Pobreza. Além disso, a partir de 2001, essa distribuição de renda diretamente à população foi mais bem coordenada pelo Projeto Alvorada, que estabeleceu uma focalização melhor de quem seriam os beneficiados, mediante um critério criativo de utilização do índice de desenvolvimento humano (IDH) dos municípios.

Todavia, o Projeto Alvorada e a noção mais coordenada de políticas de transferência de renda foram atropelados pelo ciclo eleitoral. Com a proximidade do pleito presidencial, o Presidente Fernando Henrique Cardoso também permitiu a proliferação de "bolsas" ou "vales" por vários ministérios, de modo que mais programas dividiram o bolo, muitas vezes com ausência de comunicação entre eles, o que levou ao desperdício e à dificuldade de avaliarem-se os resultados.

\section{V.3. As políticas urbanas e de desenvolvimento}

Várias ações do governo FHC poderiam ser criticadas sob o prisma federativo, mas duas delas precisam ser comentadas devido ao enorme impacto que têm. A primeira diz respeito às políticas de desenvolvimento, analisadas pelo viés do federalismo. A estrutura institucional federal montada para tratar desses problemas foi bastante débil. O Ministério da Integração Regional constituiu-se apenas em um lugar para o fisiologismo político da pior espécie, afora ter tido uma grande instabilidade no seu comando, com trocas freqüentes de titulares, muitas delas derivadas de algum escândalo.

Triste sina tiveram as instituições de coordenação do desenvolvimento regional, a Sudam e a Sudene. O Presidente Fernando Henrique Cardoso poderá dizer que foi ele quem desvelou toda uma estrutura profunda, construída por décadas, de corrupção. É óbvio que essa obra deve ser creditada ao avanço democrático ocorrido nos últimos anos, com intensa participação da imprensa e das instituições de controle, em particular aqui o Ministério Público Federal. Mas o fato cabal é que o governo FHC não teve um projeto claro de desenvolvimento regional. Ao contrário, desmantelou os órgãos incumbidos de tal tarefa, fragmentou políticas para esta área e não propôs uma alternativa ao modelo anterior.

$\mathrm{O}$ acirramento da guerra fiscal tornou-se uma marca negativa da Era FHC. O uso dessa forma de competição federativa é comprovadamente inócuo, pois a adoção dessas medidas não tem alterado a redistribuição regional dos recursos e, como mostrou o estudo de Sérgio Ferreira (2000), do Bndes, dos sete estados que mais utilizaram os instrumentos de incentivo tributário (Rio Grande do Sul, Ceará, Paraná, Espírito Santo, Goiás, Bahia e Pernambuco), somente o Ceará teve aumento na sua participação no PIB nacional entre 1985 e $1998^{12}$.

Sem dúvida, há fatores que fogem da alçada da União, como o comportamento estadualista das governadorias e os elementos da crise financeira dos estados causados por eles mesmos, resultantes do uso indiscriminado dos instrumentos pre-

\footnotetext{
12 Os resultados dos estados que utilizaram intensamente a guerra fiscal foram os seguintes: Goiás teve um decréscimo de 2\% para 1,9\%; no Rio Grande do Sul houve uma queda de $7,9 \%$ para $7 \%$; na Bahia, de 5,1\% para 4,1\%; em Pernambuco, de 2,5\% para 2,3\%; no Paraná, de 6,3\% para 5,8\%; no Espírito Santo, de 1,7\% para 1,5\%; a grande exceção, o Ceará, teve um crescimento de 1,6\% para 1,8\% (FERREIRA, 2000, p. 6).
} 
datórios ao longo da redemocratização, o que os levou a procurar atrair empresas para angariar empregos e impostos futuros. Fica a pergunta: como o governo federal poderia ter atuado nessa questão? Primeiro, realizando políticas de desenvolvimento, a partir de decisões que sejam tomadas em fóruns nacionais, em nome da transparência, da justiça redistributiva e da igualdade entre os pactuantes. Em segundo lugar, faltou uma ação mais efetiva em prol da reforma tributária. Porém, se partirmos da hipótese de que a reformulação do sistema de tributo é quase impossível de ser realizada, o papel do Presidente Fernando Henrique deveria ter sido o de colocar no debate público esse problema e condená-lo. Em vez disso, concedeu empréstimo do Bndes para a Ford, intercedendo, sem critérios, em uma batalha entre a Bahia e o Rio Grande do Sul, favorecendo o governo baiano em razão da pressão do grande cacique regional, Antônio Carlos Magalhães. Nesse caso, FHC perdeu para o legado oligárquico e patrimonialista do federalismo brasileiro.

A maior fragilidade dos anos FHC foi a ausência de políticas urbanas. É bem verdade que desde o governo Sarney elas não são prioritárias e na Era Collor houve um desmantelamento daquilo que havia. Mas o fato é que o Brasil dos anos 1990 assistiu a um processo de metropolização dos problemas, com a elevação do desemprego urbano, a piora no sistema de transporte nas grandes cidades, o crescimento da desigualdade e da pobreza metropolitanas (fenômeno bem mais complexo do que o vivido no meio rural), bem como o aumento da violência nas periferias.

O crescimento dos problemas metropolitanos ocorreu no mesmo momento em que não há políticas ou instituições capazes de dar conta dessa questão. A Constituição de 1988 foi movida por uma concepção descentralizadora municipalista, por um modelo federativo compartimentalizado e por uma aversão ao centralismo, justificável pelo impacto negativo que teve o "unionismo-autoritário" desenvolvido pelo regime militar. Contudo, quando os problemas não podem ser resolvidos sozinhos pelo poder local, envolvem mais de um ente governamental e precisam também da intervenção ativa de uma política nacional, o desenho institucional e a cultura política federalista predominante não têm respostas adequadas.

O resultado disso torna-se claro no modelo de região metropolitana (RM) concebido na Consti- tuição de 1988. Na verdade, as RMs foram esvaziadas e sua conformação legal, transferida para os estados, os quais, conforme trabalho realizado por Sérgio Azevedo e Virgínia Guia (2000), não priorizaram essa questão no seu desenho político-administrativo. Sem uma instância metropolitana e/ou formas que levem à formação de colegiados metropolitanos - com os municípios envolvidos, mais os governos estadual e federal, além da sociedade civil local -, será muito difícil resolver os dilemas dos grandes centros urbanos.

Uma ação nacional passaria pela revisão da legislação sobre as regiões metropolitanas, o que depende de revisão constitucional. O governo federal não tratou deste assunto nos anos FHC. Para além da questão mais geral, o fato é que a União não constituiu políticas adequadas para a grande maioria dos problemas metropolitanos. Isso fica claro ao observarmos o desenho institucional do poder Executivo federal em relação a essa temática. Primeiro, repassou tal preocupação à Secretaria de Políticas Urbanas, fraca institucional e politicamente, destinada a obter apoios clientelistas no Congresso Nacional. Some-se a isso o fato de que a maioria das políticas urbanas dividia-se por vários ministérios - só o saneamento estava presente em sete deles, mais a Secretaria de Políticas Urbanas. A fragmentação excessiva inviabilizou o alcance de resultados satisfatórios.

As principais políticas de cunho urbano-metropolitano fracassaram. Poderíamos citar a segurança pública, em que o governo federal descobriu tarde seu papel, reduzido ao financiamento dos estados, quando deveria atuar em rede na coordenação das polícias. No caso do saneamento, houve um problema regulatório, com a crise das empresas do setor e a errática (e equivocada) trajetória de privatização e, em termos de investimentos, embora eles tenham-se elevado no período 1995-1998, não puderem crescer mais no momento seguinte devido às restrições de acordo feito com o Fundo Monetário Internacional (FMI). Segundo Marcus Melo, a Caixa Econômica Federal, principal financiadora de infra-estrutura urbana, não firmou nenhum contrato de financiamento na área de saneamento entre 1999 e 2000 (MELO, 2002, p. 8).

Como a área de desenvolvimento urbano envolve competências e atribuições dos três níveis de governo, a coordenação federativa teria que passar, como foi feito na saúde e com o Fundef, 
pela elaboração de políticas federais indutoras, a partir das quais os governos subnacionais fossem incentivados a cooperar e a buscar determinadas metas e resultados. Além disso, como bem nota Marcus Melo, o sucesso das políticas públicas tem sido maior conquanto consigam desenvolver suas características intersetoriais, como ocorre no bolsa-escola, por exemplo. Isso é válido para vários setores do desenvolvimento urbano, em particular o Saneamento, que poderia articular-se mais com a saúde, fortalecendo os programas desta área (idem, p. 25).

O Presidente Fernando Henrique Cardoso percebeu, na passagem de um mandato a outro, que sua política urbana ia de mal a pior. Por isso cogitou de criar um ministério específico e forte para essa área, mas não teve êxito em seu intento. Ainda que longa, vale a pena citar a descrição de Caco de Paula a respeito desse processo: "Durante sua campanha pela reeleição, Fernando Henrique Cardoso chegou a anunciar a criação do Ministério do Desenvolvimento Urbano, uma superpasta que contaria com R \$ 40 bilhões, provenientes do Orçamento da União, de recursos da Caixa Econômica Federal e que, com acordos com a iniciativa privada, se dedicaria a combater os grandes déficits das áreas de habitação e saneamento. Saudado tanto por técnicos em urbanismo como por empresários do setor imobiliário esse 'Ministério da Moradia' - ou 'Ministério da Cidade' - passou a ser visto como uma possibilidade de, finalmente, o governo enfeixar as políticas de desenvolvimento urbano de forma mais integrada. Como já acontecera outras vezes, desde os tempos do regime militar, a superpasta foi motivo de muitos comentários, discussões e disputas entre os políticos aliados do Palácio do Planalto. Mas na hora em que teve de articular o xadrez ministerial para o seu segundo mandato, Fernando Henrique Cardoso abandonou a idéia. E o antigo projeto, tentado desde o fim dos governos militares, de fazer da questão urbana a grande prioridade da ação federal, novamente, ficou para o futuro" (PAULA, 2002, p. 419).

\section{OS DESAFIOS DO GOVERNO LULA}

A Era FHC teve um papel importante na mudança de alguns padrões federativos construídos ao longo da redemocratização. Em especial, teve grande êxito no ataque ao modelo predatório vinculado ao estadualismo, reduzindo as formas de repasse de custos financeiros entre os entes e co- locando fortes limites à irresponsabilidade fiscal de governadores e prefeitos. Destaque deve ser dado também para outros quatro elementos positivos: o reforço do controle social vinculado à descentralização; a adoção de políticas de coordenação intergovernamental nas políticas de saúde (com o PAB) e de educação (com o Fundef); criação de programas nacionais de transferência direta de renda, com importantes impactos redistributivos e, em menor medida, montou programas de avaliação dos gastos públicos e dos resultados das políticas, fornecendo um feedback essencial à União para coordenar a descentralização.

Os limites e os fracassos do período Fernando Henrique Cardoso são pensados aqui como o universo que compõe os desafios federativos do governo Lula. Cabe assinalar, primeiramente, três ações institucionais positivas tomadas pelo novo Presidente: o revigoramento da Secretaria de Assuntos Federativos, que nunca teve o devido poder nos anos FHC, a criação do Ministério das Cidades, unificando todas as políticas urbanas em um só local, além da reestruturação da política regional, com o Ministério da Integração Nacional. Duas medidas legislativas também apontaram para o rumo certo. Uma foi a continuação da reforma da previdência, agora mais focada no setor público, com impacto favorável à modernização dos governos estaduais - e a forma cooperativa pela qual Lula atuou junto aos governadores foi um dos pontos altos de sua gestão. A outra medida revela a assunção de uma nova visão das relações intergovernamentais. Trata-se do projeto que regulamenta os consórcios públicos, que diminuirá substancialmente os efeitos perversos do municipalismo autárquico.

Permanece uma lista longa de problemas de coordenação federativa para o governo Lula. Entre os principais, destacamos:

1) mudanças no sistema tributário, principalmente na lógica de cobrança do ICMS, a fim de neutralizar os efeitos perversos da guerra fiscal;

2) o fortalecimento dos mecanismos nacionais de avaliação de políticas públicas, tarefa bastante atrasada no atual momento;

3) auxílio na reformulação e criação de capacidades administrativas de estados e municípios, processo que teve um bom impulso no campo 
dos estados, com a criação do Programa Nacional de Apoio à Modernização da Gestão e do Planejamento dos Estados e do Distrito Federal (Pnage). Além disso, é preciso estabelecer redes e interconexões de longo prazo entre as burocracias federal, estaduais e municipais, o que favorecerá um planejamento melhor das políticas nacionais e regionais;

4) montagem de uma nova ordem regulatória e coordenadora das principais políticas urbanas, com destaque para o saneamento, a segurança pública, a habitação e o transporte. Mais uma vez, o governo Lula tem andado lentamente, quando não erraticamente, na formulação e negociação dessas políticas. Vale frisar aqui que a discussão sobre o papel e o funcionamento das regiões metropolitanas precisa estar ligada a esses assuntos;

5) ampliação e reforço dos mecanismos coordenadores nas áreas de educação - com a elaboração e aprovação do Fundeb - e saúde - com a indução para ações mais regionalizadas -;
6) aprimoramento das políticas nacionais de transferência de renda, vinculando e controlando mais o repasse de recursos a políticas de capacitação para a cidadania plena;

7) adoção de políticas de desenvolvimento que reduzam, efetivamente, as disparidades regionais do país. As boas intenções iniciais, inclusive no campo institucional, não tiveram ainda resultados palpáveis e

8) por fim, o fortalecimento dos fóruns federativos de discussão e negociação entre os níveis de governo. Decerto que os anos FHC trouxeram muitos avanços para o nosso federalismo, mas eles ocorreram em uma ação direta, informal e por vezes fragmentada do governo federal junto aos entes subnacionais. $\mathrm{O}$ aumento da consciência da importância da temática da coordenação federativa só ocorrerá com maior sustentabilidade quando instituições como o Senado, o Conselho de Gestão Fiscal e governos metropolitanos devem ser ativados para evitar o reforço perverso da dicotomia entre descentralização e centralização.

Fernando Luiz Abrucio (fabrucio@fgvsp.br) é Doutor em Ciência Política pela Universidade de São Paulo (USP), professor do Programa de Pós-graduação em Administração Pública e Governo da Fundação Getúlio Vargas de São Paulo (FGV-SP), além de lecionar Política Comparada na Pontifícia Universidade Católica de São Paulo (PUC-SP).

\section{REFERÊNCIAS BIBLIOGRÁFICAS}

ABRANCHES, S. 1988. Presidencialismo de coalizão : o dilema institucional brasileiro. $D a-$ dos, Rio de Janeiro, v. 31, n. 1, p. 5-34.

ABRUCIO, F. L. 1998. Os barões da federação : os governadores e a redemocratização brasileira. São Paulo : Hucitec.

2000. Os laços federativos brasileiros: avanços, obstáculos e dilemas no processo de coordenação intergovernamental. São Paulo. Tese (Doutorado em Ciência Política). Universidade de São Paulo.

2004. Diagnóstico geral das administrações públicas estaduais. Brasília : Ministério do Planejamento, Orçamento e Gestão.

ABRUCIO, F. L. \& SAMUELS, D. 1997. A nova política dos governadores. Lua Nova, São Paulo, n. 40-41, p. 137-166.
ABRUCIO, F. L. \& COSTA, V. M. F. 1999. Reforma do Estado e o contexto federativo brasileiro. São Paulo : Fundação Konrad Adenauer.

ABRUCIO, F. L. \& SOARES, M. 2001. Redes federativas no Brasil : cooperação intermunicipal no Grande ABC. São Paulo : Fundação Konrad Adenauer.

AFONSO, J. R. \& ARAÚJO, E. A. 2000. A capacidade de gastos dos municípios brasileiros : arrecadação própria e receita disponível. $\mathrm{Ca}$ dernos Adenauer, Rio de Janeiro, n. 4, p. 3555.

AFONSO, R. \& SILVA, P. L. B. (orgs.). 1995. A federação em perspectiva : ensaios selecionados. São Paulo : UNESP.

ARRETCHE, M. 1996. A descentralização das políticas sociais no estado de São Paulo: 
1986-94. Relatório-síntese da pesquisa : “Balanço e perspectivas da descentralização das políticas sociais no Brasil”. São Paulo : FUNDAP.

2000. Estado federativo e políticas sociais : determinantes da descentralização. Rio de Janeiro : Revan.

2004. Federalismo e políticas sociais no Brasil : problemas de coordenação e autonomia”. São Paulo em Perspectiva, São Paulo, v. 18, n. 2, p. 17-26, abr.-jun.

AZEVEDO, S. \& GUIA, V. R. M. 2000. Reforma do Estado e federalismo : os desafios da governança metropolitana. In : RIBEIRO, L. C. Q. (org.). O futuro das metrópoles : desigualdades e governabilidade. Rio de Janeiro : Revan.

BANCO MUNDIAL. 1997. O Estado em um mundo em transformação. Relatório sobre o desenvolvimento mundial. Washington, D. C. : Banco Mundial.

BELTRÃO, R.; ABRUCIO, F. L. \& LOUREIRO, M. R. 1997. Reforma da burocracia pública e federalismo no Brasil : a experiência do Programa de Demissão Voluntária nos governos estaduais. Anais do Seminário Internacional "Reforma Administrativa em Países em Desenvolvimento”. Brasília : Escola Nacional de Administração Pública.

BRESSER-PEREIRA, L. C. 1998. Reforma do Estado para a cidadania. São Paulo : ed. 34.

BURGESS, M. 1993. Federalism and Federation : A Reappraisal. In : BURGESS, M. \& GAGNON, A. (orgs.). Comparative Federalism and Federation. London : Harvester.

CAMARGO, A. 1994. O novo pacto federativo. Revista do Serviço Público, Brasília, ano 45, v. 118, n. 1, p. 87-94, jan.-jul.

CONLAN, T. 1998. From New Federalim to Devolution. Washington, D. C. : Brookings Institution.

COUTO, C. G. \& ABRUCIO, F. L. 2003. O segundo governo FHC : coalizões, agendas e instituições. Tempo Social, São Paulo, v. 15, n. 2, p. 269-301.

COSTA, N. R.; SILVA, P. L. B. \& RIBEIRO, J. M. 1999. A descentralização do sistema de saúde no Brasil. Revista do Serviço Público,
Brasília, n. 3, p. 32-55, jul.-set.

DANIEL, C. 2001. Autonomia municipal e as relações com os estados e a União. In : HOFMEISTER, W. \& CARNEIRO, J. M. B. (orgs.). Federalismo na Alemanha e no Brasil. São Paulo : Fundação Konrad Adenauer.

ELAZAR, D. 1987. Exploring Federalism. Tuscaloosa : University of Alabama.

FERREIRA, S. 2000. Guerra fiscal : competição tributária ou corrida ao fundo do poço? Estudos BNDES, Rio de Janeiro, n. 4, p. 1-6, jan.

GAGNON, A. 1993. The Political Uses of Federalism. In : BURGESS, M. \& GAGNON, A. (orgs.). Comparative Federalism and Federation. London : Harvester.

GARMAN, C.; LEITE, C. \& MARQUES, M. 1998. Impactos da relação Banco Central versus bancos estaduais no arranjo federativo pós-1994 : análise à luz do caso Banespa. Trabalho apresentado no XXII Encontro Anual da Associação Nacional de Pesquisa e Pósgradução em Ciências Sociais, realizado em Caxambu (MG), entre 27 e 31 de outubro de 1998. Digit.

GARSON, S. \& ARAÚJO, E. A. 2001. Federalismo fiscal e ações sociais básicas : descentralização ou municipalização? Boletim BNDES, Rio de Janeiro, n. 23, jan. Disponível em : http:/ /www.federativo.bndes.gov.br/bf_bancos/estudos/e0001366.pdf. Acesso em : 2.jun.2005.

GERZONI, G. 1996. Tentativas e perspectivas de formação de uma burocracia pública no Brasil. Revista do Serviço Público, Brasília, v. 120, n. 1, p. 41-66, jan.-abr.

KUGELMAS, E. \& SOLA, L. 1999. Recentralização-descentralização : dinâmica do regime federativo no Brasil dos anos 90. Tempo Social, São Paulo, v. 11, n. 2, p. 63-81, out.

LICIO, E. C. 2002. A trajetória dos programas de renda mínima e bolsa escola no Brasil : o impacto da variável federativa. São Paulo. Dissertação (Mestrado em Administração Pública e Governo). Fundação Getúlio Vargas.

LOUREIRO, M. R. \& ABRUCIO, F. L. 2004. Política e reformas fiscais no Brasil recente. Revista de Economia Política, São Paulo, v. 24, n. 1, p. 50-72, jan.-mar. 
MELO, M. A. 2002. Políticas públicas urbanas para a nova década : uma agenda de questões. Recife : digit.

MORA, M. 2002. Federalismo e dívida estadual no Brasil. Texto para discussão n. 866. Rio de Janeiro : Instituto de Pesquisas Econômicas Aplicadas.

NUNES, E. 1997. A gramática política do Brasil. Rio de Janeiro : J. Zahar.

OECD. 1997. In Search of Results. Performance, Management, Practices. Paris : Organization for Economic Cooperation and Development.

PAULA, C. 2002. Política urbana. In : LAMOUNIER, B. \& FIGUEIREDO, R. (orgs.). A Era FHC : um balanço. São Paulo : Cultura.

PETERSON, P. 1995. The Price of Federalism. Washington. D. C. : The Brookings Institution.

PIERSON, P. 1995. Fragmented Welfare States : Federal Instiutions and the Development of Social Policy. Governance, Cambridge, Mass., v. 8 , n. 4 , p. $448-478$, Oct.

2000. Increasing Returns, Path Dependece and the Study of Politics. American Political Science Review, Washington, D. C., v. 94, n. 2, p. 251-267, June.

POCOCK, J. G. A. 1975. The Machiallevian Moment. Princeton : Princeton University.

PRUD'HOMME, R. 1995. The Dangers of Decentralization. World Bank Research Observer, Oxford, v. 10, n. 2, p. 201-220, Aug.

REZENDE, F. 2001. Compensações financeiras e desequilíbrios fiscais na federação brasileira. In : HOFMEISTER, W. \& CARNEIRO, J. M. B. (orgs.). Federalismo na Alemanha e no Brasil. São Paulo : Fundação Konrad Adenauer.

SALLUM JÚNIOR, B. 1999. O Brasil sob Cardoso : neoliberalismo e desenvolvimentismo. Tempo Social, São Paulo, v. 11, n. 2, p. 2347, out.

SCHARPF, F. 1988. The Joint Decision Trap : Lessons from German Federalism and European Integration. Public Administration, v. 66, p. 80-117, Autumm.

SINGER, A. 2002. Saúde. In : LAMOUNIER, B. \& FIGUEIREDO, R. (orgs.). A Era do Real : um balanço. São Paulo : Cultura.

SOLA, L.; GARMAN, C. \& MARQUES, M. 1998. Central Banking, Democratic Governance and Political Authority : The Case of Brazil in a Regional Perspective. Revista de Economia Política, São Paulo, v. 18, n. 2, p. 106-131, abr.-jun.

SOUZA, C. 1996. Redemocratization and Decentralization in Brazil : The Strength of the Member States. Development and Change, London, v. 27, n. 3, p. 529-555.

1998. Federalismo e intermediação de interesses regionais nas políticas públicas brasileiras. Artigo apresentado no Seminário Internacional "Reestruturação e reforma do Estado : Brasil e América Latina no processo de globalização”, realizado em São Paulo, no mês de junho. Digit.

STEPAN, A. 1999. Para uma análise comparativa do federalismo e da democracia : federações que restringem ou ampliam o poder do demos. Dados, Rio de Janeiro, v. 42, n. 2, p. 197-251.

TENDLER, J. 1998. Bom governo nos trópicos : uma visão crítica. Brasília : Escola Nacional de Administração Pública.

TIEBOUT, C. A. 1956. A Pure Theory of Local Expenditures. Journal of Political Economy, Chicago, v. 64, p. 416-424, Oct.

WATTS, R. 1999. Models of Federal Power Sharing. Digit.

WERNECK, R. 1998. A União e a dívida dos estados. O Estado de São Paulo, 13.jun., p. B2.

WERNECK VIANNA, L. (org.). 1999. A judicialização da política e das relações sociais no Brasil. Rio de Janeiro : Revan.

WILLIS, E.; GARMAN, C. \& HAGGARD, S. 1999. The Politics of Decentralization in Latin America. Latin American Research Review, New Mexico, v. 34, n.1, p. 7-56.

WRIGHT, D. S. 1997. Para entender las relaciones intergubernamentales. Ciudad de México : Fondo de Cultura Económica.

ZIMMERMAN, J. F. 1992. Contemporary American Federalism. London : Praeger. 


\section{OUTRAS FONTES}

BRASIL. 1988. Constituição da República Federativa do Brasil. Brasília : Senado Federal. Disponível em : https://www.presidencia.gov.br/ casacivil/site/static/le.htm. Acesso em : 15.jun.2004.
BRASIL. Banco Central do Brasil. 1992. Bancos estaduais. Experiências e perspectivas. Brasília : Banco Central do Brasil.

Gazeta Mercantil. 2000. 9.fev., p A-20. 
Versão dos resumos para o inglês: Miriam Adelman

FEDERATIVE COORDINATION IN BRAZIL: THE EXPERIENCE FROM THE FHC ADMINISTRATION TO THE CHALLENGES OF THE LULA GOVERNMENT

\section{Fernando Luiz Abrucio}

With re-democratization, the rebirth of the Brazilian federation brought with it a series of auspicious aspects. Yet Brazil must also face up to the growing dilemas on inter-governmental coordination that have been ascertained internationally, as they pertain to Brazilian historical specificities. The present article concentrates primarily on the study of problems and actions of federative coordination that have arisen recently in Brazil, particularly during the administration of ex-president Fernando Henrique Cardoso. This analysis also aims to summarize the challenges of inter-governmental coordination that the Lula government must now face.

KEYWORDS: federation; centralization; FHC administration; Lula government. 
Versão dos resumos para o francês: Maria Fernanda Araújo Lisboa

LA COORDINATION FEDERATIVE AU BRÉSIL : L’EXPERIENCE DE LA PERIODE FERNANDO HENRIQUE CARDOSO (FHC) ET LES DEFIS SOUS LULA

Fernando Luiz Abrucio

La renaissance de la fédération brésilienne, grâce à la redémocratisation, annonce de bonnes pespectives, mais il faut aussi que le Brésil fasse face à des difficultés de coordination entre les régions qui ont été ressentis internationalement, d'après les spécificités historiques de notre réalité. Cet article s'en tient à l'étude des problèmes et actions de coordination fédérative survenues récemment au Brésil, particulièrement dans la période du gouvernement du président Fernando Henrique Cardoso. A partir de cette analyse, on présente, à la fin et brièvement, les défis de coordination d'intégration gouvernementale pour le président Lula.

MOTS-CLES : fédération; centralisation; décentralisation; gouvernement FHC; gouvernement Lula. 